\title{
Evolution of seismic layer 2B across the Juan de Fuca Ridge from hydrophone streamer 2-D traveltime tomography
}

\author{
Kori R. Newman \\ Lamont-Doherty Earth Observatory, Earth Institute at Columbia University, Palisades, New York \\ 10964, USA \\ Department of Earth and Environmental Sciences, Columbia University, New York, New York \\ 10027, USA
}

Now at Raytheon BBN Technologies, Arlington, Virginia 22209, USA

\section{Mladen R. Nedimović}

Department of Earth Sciences, Dalhousie University, Rm. 3006, Life Sciences Centre, Halifax, Nova ScotiaB3H 4J1, Canada (mladen@dal.ca)

Lamont-Doherty Earth Observatory, Earth Institute at Columbia University, Palisades, New York 10964, USA

\section{J. Pablo Canales}

Woods Hole Oceanographic Institution, Woods Hole, Massacbusetts 02543, USA

\section{Suzanne M. Carbotte \\ Lamont-Doherty Earth Observatory, Earth Institute at Columbia University, Palisades, New York 10964, USA}

[1] How oceanic crust evolves has important implications for understanding both subduction earthquake hazards and energy and mass exchange between the Earth's interior and the oceans. Although considerable work has been done characterizing the evolution of seismic layer $2 \mathrm{~A}$, there has been little analysis of the processes that affect layer 2B after formation. Here we present high-resolution 2-D tomographic models of seismic layer $2 \mathrm{~B}$ along $\sim 300 \mathrm{~km}$ long multichannel seismic transects crossing the Endeavour, Northern Symmetric, and Cleft segments of the Juan de Fuca Ridge. These models show that seismic layer 2B evolves rapidly following a different course than layer $2 \mathrm{~A}$. The upper layer $2 \mathrm{~B}$ velocities increase on average by $0.8 \mathrm{~km} / \mathrm{s}$ and reach a generally constant velocity of $5.2 \pm 0.3 \mathrm{~km} / \mathrm{s}$ within the first $0.5 \mathrm{Myr}$ after crustal formation. This suggests that the strongest impact on layer $2 \mathrm{~B}$ evolution may be that of mineral precipitation due to "active" hydrothermal circulation centered about the ridge crest and driven by the heat from the axial magma chamber. Variations in upper layer $2 \mathrm{~B}$ velocity with age at time scales $\geq 0.5 \mathrm{Ma}$ show correlation about the ridge axis indicating that in the long term, crustal accretion processes affect both sides of the ridge axis in a similar way. Below the $0.5 \mathrm{Ma}$ threshold, differences in $2 \mathrm{~B}$ velocity are likely imprinted during crustal formation or early crustal evolution. Layer $2 \mathrm{~B}$ velocities at propagator wakes $(5.0 \pm$ $0.2 \mathrm{~km} / \mathrm{s}$ ), where enhanced faulting and cracking are expected, and at areas that coincide with extensional or transtensional faulting are on average slightly slower than in normal mature upper layer 2B. Analysis of the layer 2B velocities from areas where the hydrothermal patterns are known shows that the locations of current and paleohydrothermal discharge and recharge zones are marked by reduced and increased upper layer 2B velocities, respectively. Additionally, the distance between present up-flow and down-flow zones is related to the amount of sediment cover because, as sediment cover increases and basement outcrops become 
covered, direct pathways from the igneous basement through the seafloor are cut off, forcing convective cells to find alternate paths.

Components: 13,700 words, 12 figures, 2 tables.

Keywords: layer 2B evolution; 2-D traveltime tomography; multichannel seismics; Juan de Fuca Ridge flanks.

Index Terms: 3025 Marine Geology and Geophysics: Marine seismics (0935, 7294); 3035 Marine Geology and Geophysics: Midocean ridge processes.

Received 3 December 2010; Revised 28 March 2011; Accepted 30 March 2011; Published 17 May 2011.

Newman, K. R., M. R. Nedimović, J. P. Canales, and S. M. Carbotte (2011), Evolution of seismic layer 2B across the Juan de Fuca Ridge from hydrophone streamer 2-D traveltime tomography, Geochem. Geophys. Geosyst., 12, Q05009, doi:10.1029/2010GC003462.

\section{Introduction}

[2] Ophiolite studies, in situ investigations from submersibles and drilling show that oceanic crust formed at ridges with fast to intermediate spreading rates is composed, from top to bottom, of basaltic extrusive rocks, sheeted diabase dikes, and massive and layered gabbros [e.g., Christensen and Smewing, 1981; Karson, 1998]. Partitioning of the oceanic crust into three layers is also observed remotely by analysis of geophysical information, mostly from controlled source seismic data [e.g., Raitt, 1963; Talwani et al., 1971; Houtz and Ewing, 1976]. Seismically identified oceanic crustal layers are named $2 \mathrm{~A}, 2 \mathrm{~B}$ and 3 . Layer $2 \mathrm{~A}$, found at the top of the igneous crust, is relatively thin $(0.35-0.65 \mathrm{~km}$ average off-axis thickness), porous $(\sim 10 \%-30 \%)$, and characterized by low $\mathrm{P}$ wave velocities (from $<2.5 \mathrm{~km} / \mathrm{s}$ at the ridge axes to $>4 \mathrm{~km} / \mathrm{s}$ in mature oceanic crust) [e.g., Berge et al., 1992; Carbotte and Scheirer, 2004]. Layer 3, representing the lower crust, is thick $(\sim 3.5-5 \mathrm{~km})$, least porous $(<5 \%)$, and characterized by the highest $\mathrm{P}$ wave velocities within the oceanic crust (6.5-7.4 km/s) [e.g., Christensen and Salisbury, 1975]. Sandwiched between layers $2 \mathrm{~A}$ and 3 is layer $2 \mathrm{~B}$. This layer has intermediate thickness (up to $1.5-2.0 \mathrm{~km})$, porosity $(<10 \%)$, and P wave velocity $(\sim 5.0-6.5 \mathrm{~km} / \mathrm{s})$ [Detrick et al., 1994; Carbotte and Scheirer, 2004].

[3] The seismically determined oceanic crustal layers are characterized by positive vertical $\mathrm{P}$ wave velocity gradients. Based on the magnitude of the velocity gradient, layer $2 \mathrm{~A}$ is divided into lowvelocity, low-gradient upper section followed by a thinner (100-300 m) high-gradient interval [e.g., Vera et al., 1990; Harding et al., 1993]. Layers 2B and 3, like upper layer $2 \mathrm{~A}$, are low-gradient areas, with layer 3 being seismically the most homogeneous (lowest velocity gradient) region within the oceanic crust [e.g., Mutter and Mutter, 1993; Cudrak and Clowes, 1993; Carbotte and Scheirer, 2004].

[4] The relationship between the lithological units of the igneous oceanic crust and the seismically determined layering is still debated. Some believe that the seismic layers $2 \mathrm{~A}, 2 \mathrm{~B}$ and 3 correspond to the lithologic counterparts: basaltic extrusives, diabase dikes, and massive/layered gabbros, respectively, with the high-gradient zone at the base of $2 \mathrm{~A}$ corresponding to a transitional zone between the pillows and dikes [Toomey et al., 1990; Harding et al., 1993; Kent et al., 1994; Vera and Diebold, 1994; Kappus et al., 1995; Christeson et al., 1996; Carbotte et al., 1997; Hussenoeder et al., 2002a, $2002 \mathrm{~b}]$. Others propose that the high-gradient transition zone at the base of layer $2 \mathrm{~A}$ is an alteration front, located within either the pillows or the dikes [McClain et al., 1985; Becker et al., 1989; Wilcock et al., 1992; Christeson et al., 2007]. Regardless of its geologic nature, it is widely accepted that the steep vertical velocity gradient that defines the seismic layer $2 \mathrm{~A} / 2 \mathrm{~B}$ boundary represents a porosity transition zone within the upper crust [e.g., Berge et al., 1992; Carbotte and Scheirer, 2004]. Furthermore, for regions with a steady state magma chamber and little or no off-axis variation in layer $2 \mathrm{~A}$ thickness over time (e.g., East Pacific Rise), the well-defined base of layer $2 \mathrm{~A}$ is likely both a lithologic boundary and alteration/permeability front [Karson and Christeson, 2003].

[5] The most striking and the best studied change taking place in the oceanic crust as it ages occurs within layer $2 \mathrm{~A}$. $\mathrm{P}$ wave velocities in this seismic layer rapidly increase after its formation, reaching typical layer $2 \mathrm{~A}$ velocities for mature oceanic crust 
of $\sim 4.3 \mathrm{~km} / \mathrm{s}$ within $<10 \mathrm{Myr}$ of crustal formation [Purdy and Ewing, 1986; Grevemeyer and Weigel, 1996; Carlson, 1998]. While more recent studies show that reaching mature layer $2 \mathrm{~A}$ velocities may, at some places, take up to $20 \mathrm{Myr}$ [Nedimović et al., 2008], the near doubling of layer 2A velocity is clearly an early crustal evolutionary process thought to be caused by precipitation of low-temperature hydrothermal alteration minerals that fill in pore spaces [Houtz and Ewing, 1976; Jacobson, 1992]. What is not known is if the same processes extend into seismic layer $2 \mathrm{~B}$, and if the sealing sedimentary cover that is known to strongly affect layer $2 \mathrm{~A}$ evolution [e.g., Rohr, 1994; Nedimović et al., 2008] has any effect on layer $2 \mathrm{~B}$ velocities. The existing studies that sampled this layer show little correlation of 2B velocity with crustal age [e.g., Houtz and Ewing, 1976; Cudrak and Clowes, 1993; Grevemeyer et al., 1998], except during the first 0.3-0.5 Myr [Vera et al., 1990; Cudrak and Clowes, 1993; Detrick et al., 1994; Crawford et al., 1999; Baran et al., 2010]. However, although pioneering, these studies did not specifically target layer $2 \mathrm{~B}$ and are either 1-D investigations not designed to systematically examine layer $2 \mathrm{~B}$ evolution along single flow lines [Houtz and Ewing, 1976], or are based on sparse 2-D data sets of limited resolving power collected using only a few ocean bottom seismometers (OBS) [Cudrak and Clowes, 1993; Grevemeyer et al., 1998].

[6] Seismic layer 2A thickens within a few kilometers of the ridge axis. This process is particularly pronounced at fast spreading centers where layer $2 \mathrm{~A}$ doubles or triples in thickness [e.g., Kent et al., 1994], but is also important at intermediate spreading rates where layer $2 \mathrm{~A}$ can double in thickness [e.g., Canales et al., 2005]. Two hypotheses exist to explain this observation: (1) thickening of layer 2A is due to the emplacement of igneous material off axis (constructional volcanism) [e.g., Macdonald et al., 1989; Toomey et al., 1990; Vera and Diebold, 1994; Hooft et al., 1996] and (2) thickening of layer $2 \mathrm{~A}$ is caused by a deepening of the hydrothermally driven cracking front that converts some of layer 2B to 2A [e.g., Lister, 1974; Kelley et al., 2002]. The thickening of layer $2 \mathrm{~A}$ by constructional volcanism is well supported because ridge magmatic eruptions that extend significant distances from the axis and off-axis lava flows have been observed at the seafloor [e.g., Haymon et al., 1993; Soule et al., 2007] and detected with geochemical studies [e.g., Perfit et al., 1994; Goldstein et al., 1994]. Evidence for layer 2A thickening by a downward propagating cracking front has been challenging to gather as this process is proposed to operate at depths greater than a couple hundreds meters below the seafloor. Therefore, it is not known if the downward propagating cracking front processes can thin layer $2 \mathrm{~B}$ and thicken layer $2 \mathrm{~A}$, and if so, how much these processes contribute to overall layer $2 \mathrm{~A}$ thickening.

[7] We present hydrophone streamer 2-D traveltime tomography results along $\sim 300 \mathrm{~km}$ long transects across the axes of the Endeavour, Northern Symmetric and Cleft segments of the Juan de Fuca Ridge to examine the velocity structure of the uppermost portion of seismic layer $2 \mathrm{~B}$. This is the first tomographic study that specifically targets layer 2B velocity structure. The main goals of the study were to investigate how layer 2B evolves with crustal age, the effect of the sealing sedimentary cover on this process, and if the evolution of layer $2 \mathrm{~B}$ is coupled with that of $2 \mathrm{~A}$. An additional motivation for the study was to determine what contributions, if any, the downward propagating cracking front processes have on off-axis thickening of layer $2 \mathrm{~A}$. Our systematic and detailed 2-D approach to extracting high-resolution layer $2 \mathrm{~B}$ velocity structure was possible for two reasons: (1) layer $2 \mathrm{~B}$ structure is densely sampled because the experimental geometry included a long multichannel seismic (MCS) hydrophone streamer $(6 \mathrm{~km})$ with closely spaced receivers $(12.5 \mathrm{~m})$ and shots $(37.5 \mathrm{~m})$ and (2) detailed velocity structure of layer $2 \mathrm{~A}$ already existed along the investigated MCS profiles [Nedimović et al., 2008]. In that sense, the Juan de Fuca Ridge is an ideal place to study layer 2B structure and its relationship to $2 \mathrm{~A}$ trends.

\section{Geologic Setting}

[8] The Juan de Fuca Ridge is a NNE striking, intermediate rate $(56 \mathrm{~mm} / \mathrm{yr})$ spreading center at the boundary between the Pacific and Juan de Fuca plates, located offshore of the U.S. Pacific northwest (Figure 1). The ridge is composed of seven segments, each with the spreading axis expressed as a shallowly rifted bathymetric high. This morphology is similar to what is expected at fast spreading ridges and may reflect increased mantle temperatures due to the presence of the Cobb hot spot [Hooft and Detrick, 1995] and other small melt anomalies in the region [Carbotte et al., 2008].

[9] Morphology of the eastern and western ridge flanks displays distinct differences due to the uneven distribution of seamounts. The seamounts generally occur on the western flank (Pacific plate) with only a 


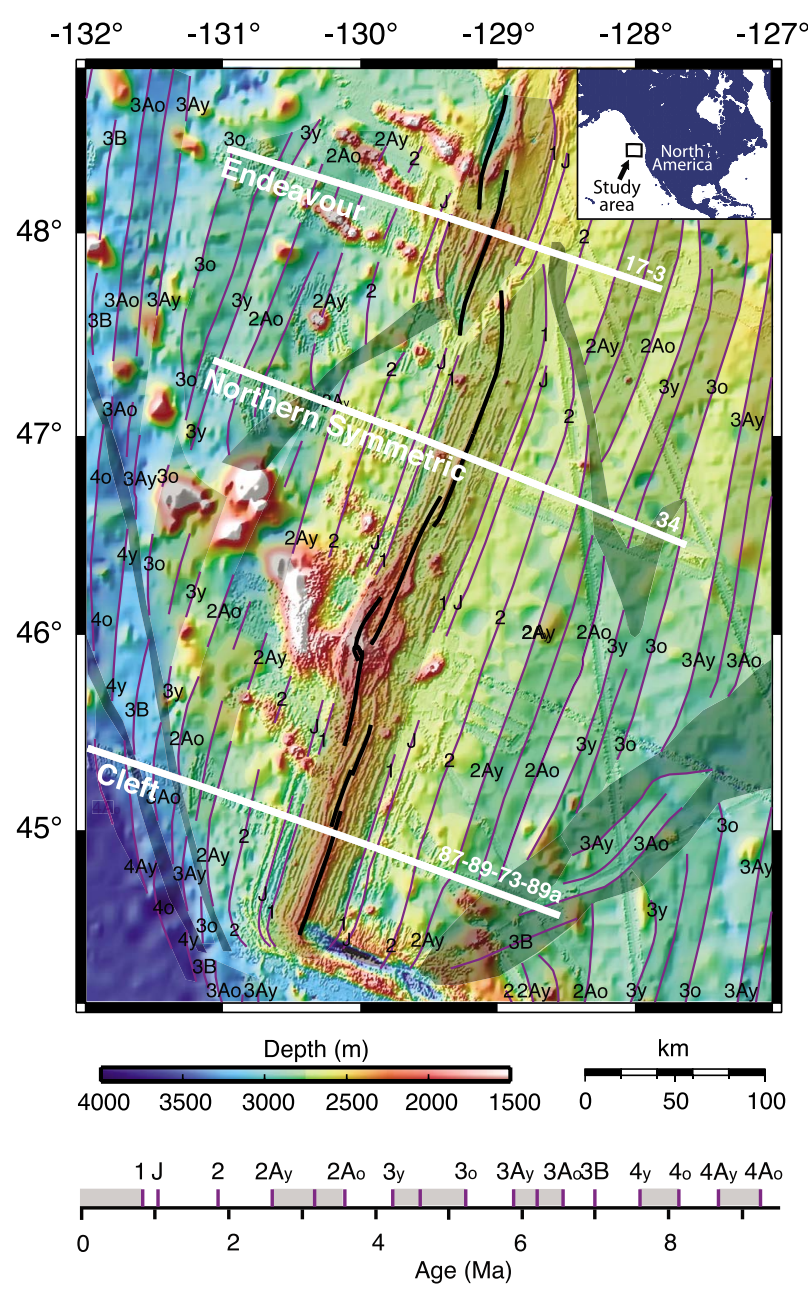

Figure 1. Overview map of our study area, the Endeavour, Northern Symmetric, and Cleft segments of Juan de Fuca Ridge. Superimposed on the color bathymetry are the locations of our seismic transects (white lines), the ridge axis (black), magnetic isochrones from Wilson [1993] (purple, with times of normal polarity denoted by lighter shading), and the locations of propagator wakes (darker shading). Note that the transect numbers are derived from the names of the MCS profiles they are composed of. Inset shows the location of the study area relative to North America.

few to the east of the ridge axis (Juan de Fuca plate) [Davis and Karsten, 1986]. Another unique characteristic of the Juan de Fuca Ridge is the uneven distribution of sediments on the two flanks as well as in the N-S direction. The eastern flank is heavily sedimented, particularly in the north-central area. This allows for an assessment of the affect of sediment cover on underlying basement velocities [Nedimović et al., 2008].

[10] Previous seismic investigation by Nedimović et al. [2008] shows that 2A velocities increase with distance from the ridge axis and that the heavily sedimented eastern flanks of the ridge segments have a more rapid increase in $2 \mathrm{~A}$ velocities. Additionally, 2A velocities appear to be higher in conjunction with propagator wakes that are mapped on both ridge flanks. Layer 2A thickness does not systematically vary with distance from the ridge axes, but $2 \mathrm{~A}$ thickness on the sediment-blanketed eastern flanks of the Endeavour and Northern Symmetric segments is less than on the sparsely sedimented corresponding western flanks and the Cleft segment flanks.

\subsection{Endeavour Segment}

[11] The Endeavour segment is the northernmost segment in our study. Its $\sim 90 \mathrm{~km}$ long ridge axis is centered within a $40 \mathrm{~km}$ wide plateau of thicker crust [Carbotte et al., 2008]. The central region of the segment intersects with the projection of the Heckle seamount chain and its morphology and recent tectonic history suggests that this segment is influenced by the melt anomaly associated with the seamounts [Karsten et al., 1986; Karsten and Delaney, 1989; Carbotte et al., 2008].

[12] This segment hosts numerous high-temperature vent fields that overlie a crustal magma body [Tivey and Delaney, 1986; Robigou et al., 1993; Lilley et al., 1995; Kelley et al., 2001, 2002, 2003; Van Ark et al., 2007]. Our Endeavour transect (Figure 1) crosses the Salty Dawg vent field, a $\sim 500 \mathrm{~m}$ long vent field [Lilley et al., 1995]. Earthquake swarms, likely indicating a diking event, occurred in June 1999 and January 2000 [Bohnenstiehl et al., 2004], a few years before our data were collected.

\subsection{Northern Symmetric Segment}

[13] The $\sim 150 \mathrm{~km}$ long Northern Symmetric segment is the longest segment of the Juan de Fuca Ridge [Christeson et al., 1993]. It was thought to be currently volcanically inactive [Kappel and Ryan, 1986; Christeson et al., 1993] until Carbotte et al. [2006] imaged an axial magma chamber beneath it. Northern Symmetric's interaction with the Endeavour Segment to the north is recorded by the Cobb Offset which shows that the Northern Symmetric segment propagated northward beginning $\sim 4.5 \mathrm{Myr}$ ago, then began to retreat $\sim 0.8 \mathrm{Myr}$ ago, and now has been propagating northward again for the past 0.1 Myr [Wilson, 1993; Shoberg et al., 1991; Carbotte et al., 2008]. Our Northern Symmetric transect crosses the southern part of this segment, intersecting a seamount just west of the ridge axis (Figure 1). 


\subsection{Cleft Segment}

[14] The Cleft segment is the southernmost segment of the Juan de Fuca Ridge, bounded by the Blanco fracture zone to the south and having $\sim 15 \mathrm{~km}$ overlap with the Vance segment to the north [Wilson, 1993]. Its morphology is characterized as a rifted, broad, axial high that, similar to Endeavour, sits on a $32 \mathrm{~km}$ wide plateau of thicker crust [Carbotte et al., 2008]. Seismic reflection imaging reveals an axial magma chamber that is offset slightly to the east of the axial topographic peak [Canales et al., 2005; Nedimović et al., 2008].

[15] Our transect crosses the northern part of the Cleft segment (Figure 1), a region that erupted in the 1980s [Chadwick et al., 1991] and which contains low-temperature hydrothermal vents [Embley et al., 1991]. Axial basalts in this area are characterized as young sheet flows that are more primitive in composition than those on southern part of the Cleft segment and more evolved than those found on the Vance segment, indicating that this is a region of increased magmatism with a well developed magma lens and the necessary subsurface infrastructure to drive organized hydrothermal venting [Smith et al., 1994].

\section{Data and Methods}

\subsection{Seismic Data}

[16] The three ridge flank transects chosen for this study cross the Endeavour, Northern Symmetric and Cleft segments and are composed of seven MCS profiles (Figure 1). These transects are well suited for an investigation of upper oceanic crustal structure and evolution as they extend for some $300 \mathrm{~km}$ reaching to crustal ages of 5-9 Ma. The excellent quality of the collected MCS data and the length of the hydrophone streamer $(6 \mathrm{~km})$ allow for a detailed 2-D tomographic investigation to be carried out.

[17] The MCS data were acquired in 2002 aboard the R/V Maurice Ewing (cruise EW0207). The acoustic sound source was a 10 gun, $49.2 \mathrm{~L}$ $\left(3005 \mathrm{in}^{3}\right)$ air gun array with shots every $37.5 \mathrm{~m}$. Receiver groups were spaced at $12.5 \mathrm{~m}$ along a 480 channel Syntron digital streamer. The air guns were towed at a nominal depth of $7.5 \mathrm{~m}$ and the streamer at a depth of $7.5 \mathrm{~m}$ during the Endeavour and Northern Symmetric transects and at $10 \mathrm{~m}$ for the Cleft transect. Streamer depth and feathering were monitored with 13 depth controlling and 11 compass-enhanced DigiCourse birds, plus a
GPS receiver on the tail buoy. Data were recorded in $10.24 \mathrm{~s}$ long records with a sampling rate of $2 \mathrm{~ms}$.

\subsection{Data Analysis}

[18] Examination of shot gathers shows that, on average, the 2B refraction arrives ahead of the seafloor reflection over approximately the far third of the streamer at source-receiver offsets between 4 and $6 \mathrm{~km}$ (Figures 2 and 3). Promax software was used to mildly band-pass and F-K filter the data to suppress streamer noise before picking the arrival times of the $2 \mathrm{~B}$ refraction. The filtering process was tested to ensure that there was no impact on the arrival time and waveform of the $2 \mathrm{~B}$ refraction. Peaks of the first arriving waveform were picked using an automatic picker followed by a visual check, after which five-point smoothing was applied. A uniform $20 \mathrm{~ms}$ pick error was assigned to all the picked arrivals. Due to the high density of data, every fifth shot was picked and later the picks were decimated for every tenth trace. Testing showed that picking $2 \mathrm{~B}$ arrivals at a greater density does not result in inversions of greater accuracy or resolution. In total, $\sim 700,000$ arrivals were picked, of which $\sim 70,000$ (Figure 3) were used to compute tomography models.

[19] P wave 2-D traveltime tomography was performed using FAST software [Zelt and Barton, 1998]. This software requires that picks be first arrivals. Due to the large water depth, the 2B refraction picks are not first arrivals because they arrive after the direct water wave. Thus, as in the work by Canales et al. [2008], a modified version of the ray tracing algorithm was used to eliminate the direct water wave path. The forward problem was computed on a grid with $25 \mathrm{~m}$ node spacing and the inverse problem was solved on a grid with $200 \mathrm{~m}$ node spacing. The length of the seismic transects and computer memory limitations required dividing the transects into shorter segments and performing tomography individually on each of the segments. The shorter segments were $42 \mathrm{~km}$ long and, when possible, overlapped by $12 \mathrm{~km}$.

[20] Starting velocity models for the inversion were constructed using all available information. Detailed velocity analyses along the investigated transects had previously been performed on the sediments and layer 2A [Nedimović et al., 2005, 2008]. Sediment velocity was determined at every $300 \mathrm{~m}$ along the transects from reflection hyperbolic normal move outs. The depths to the seafloor and crust were derived from reflection images, computed sediment velocities and an assumed water velocity of $1.5 \mathrm{~km} / \mathrm{s}$. 

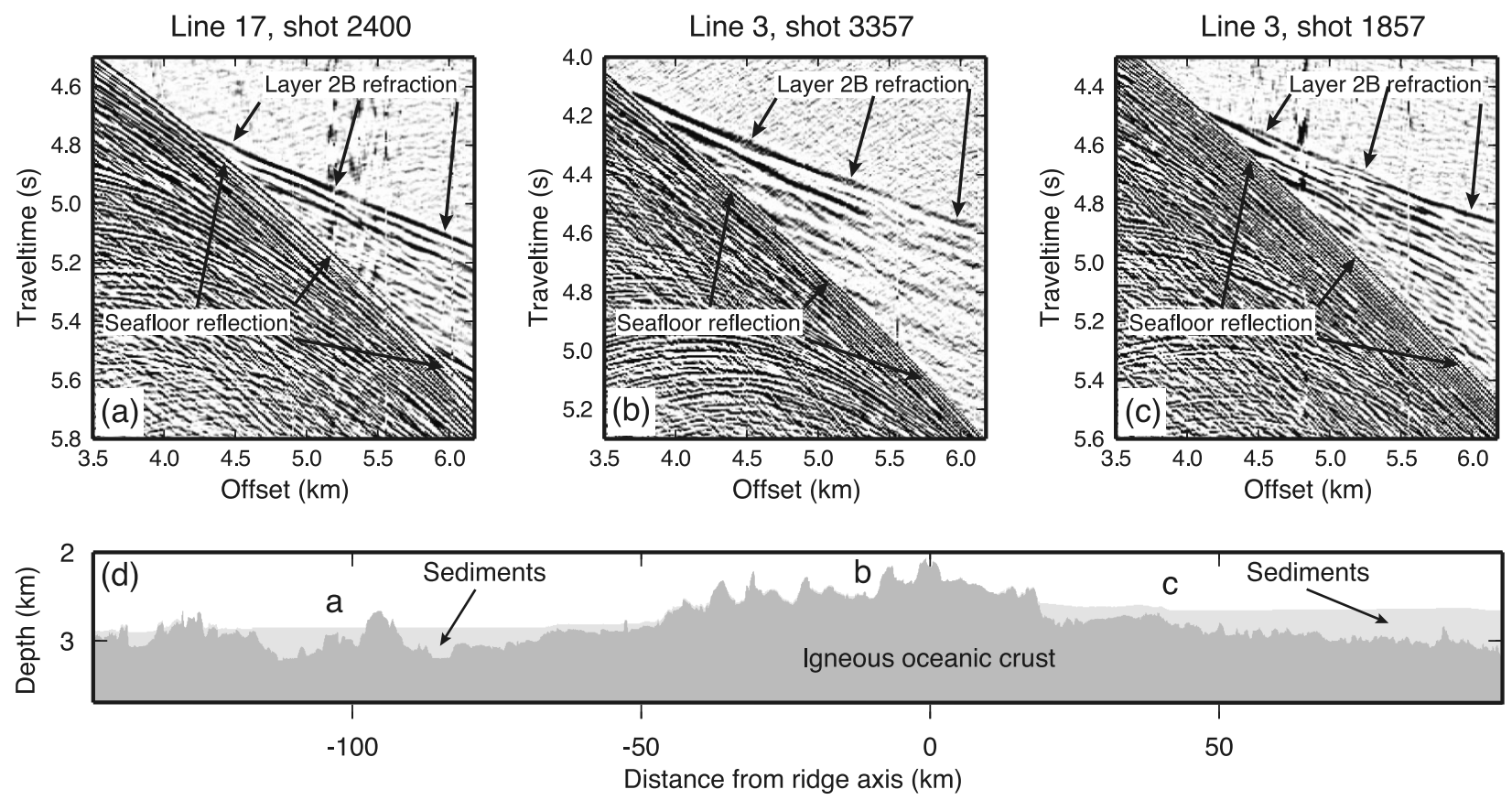

Figure 2. $(\mathrm{a}-\mathrm{c})$ Three representative shot gathers from the Endeavour transect showing layer 2B refracted arrivals emerging from the seafloor reflection at source-receiver offsets from $\sim 4-6 \mathrm{~km}$. The presented gathers were chosen to cover (d) a range of oceanic crustal environments from thicker sediments and rougher basement (Figure 2a) to smoother and barren igneous crust (Figure $2 b$ ) or crust covered with thin sediments (Figure 2c). Note that the $\mathrm{S} / \mathrm{N}$ ratio is generally high and accurate picking of layer $2 \mathrm{~B}$ arrivals was a straightforward process.

Layer 2A velocity and thickness data, spaced about every $3 \mathrm{~km}$, were extracted from 1-D traveltime modeling on CMP supergathers that incorporated linear velocity gradient layers. A constant velocity gradient layer $2 \mathrm{~B}$ was hung from the base of $2 \mathrm{~A}$, and the bottom of $2 \mathrm{~A} /$ top of $2 \mathrm{~B}$ was forced to be the same velocity across the all segments that belong to the same transect. Starting velocity models were tested by computing and analyzing $\chi^{2}$ (chi-square) values for a range of $2 \mathrm{~B}$ velocity gradients and $2 \mathrm{~A} / 2 \mathrm{~B}$ boundary velocities (Figure 4). Results showed that the preferred starting velocity model was more dependent on the top of $2 \mathrm{~B}$ velocity and less so on 2B velocity gradient (Figure 4). Thus, an intermediate $2 \mathrm{~B}$ velocity gradient of $0.5 \mathrm{~s}^{-1}$ was assigned to the starting models of all three profiles. The starting top of 2B velocities for Endeavour, Northern Symmetric and Cleft segments were set at 5.0, 4.9 and $5.1 \mathrm{~km} / \mathrm{s}$, respectively.

[21] Regularization of the inverse problem was done by imposing smoothing constraints on the model perturbations using second-derivative operators, both in the horizontal and vertical directions, thus minimizing the curvature of the velocity perturbations [Zelt and Barton, 1998]. Smoothing in the horizontal direction was set to be much stronger than in the vertical direction (by a factor of $\sim 13$ ). To test the appropriate value for $\lambda$, the damping parameter that controls the trade-off between minimizing data residuals or obtaining a solution that satisfies the smoothing constraints, multiple inversions were computed with varying $\lambda$ values. The preferred models were those computed with the highest $\lambda$ value while still converging at $\chi^{2} \leq 1.1$. This ensures that the data are well fit without fitting the noise and that no structures are imaged that would not appear in a rougher model that would fit the data equally well [Canales et al., 2008; Zelt et al., 2004].

\subsection{Resolution Tests}

[22] Several tests were conducted to determine the lateral resolution of our velocity models. Resolution testing need only be performed on the resulting model from one transect because the same type of data were recorded using the same acquisition system and all three transects cross similar types of structures. Thus, resolution testing was limited to the Endeavour velocity model with the assumption that the results could be extended to the Northern Symmetric and Cleft segments. 


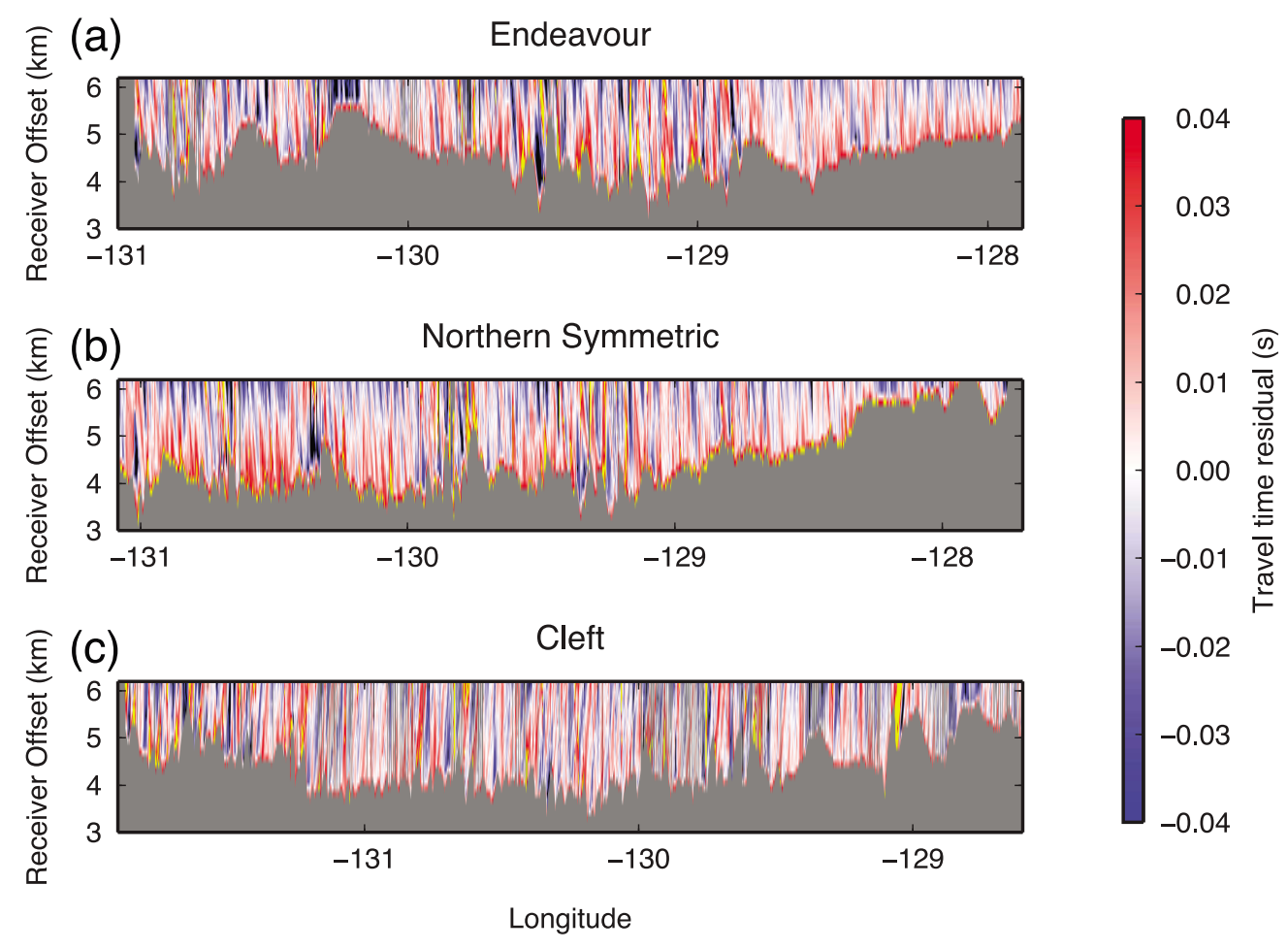

Figure 3. Plots of misfit (traveltime residuals) between the picked 2B arrivals and the ray traveltimes through the preferred starting velocity model are shown in color for the (a) Endeavour, (b) Northern Symmetric, and (c) Cleft transects as a function of shot longitude and source-receiver offset. Residuals smaller than $-40 \mathrm{~ms}$ and greater than $40 \mathrm{~ms}$ are shown in black and yellow, respectively. These anomalous areas generally coincide either with raypaths that the ray tracing algorithm incorrectly interprets as reflections or at the edges of segment seams where there is little overlap and, thus, poor ray coverage. The $2 \mathrm{~B}$ refraction arrives before the seafloor reflection in far offsets, generally greater than $4 \mathrm{~km}$. Gray areas indicate sections where no traveltimes were picked for a particular shot-receiver pair because of noisy data or because layer 2B refractions arrive later than the seafloor reflection at short offsets and where the sediment cover is very thick (e.g., at the eastern end of the Northern Symmetric transect).

[23] Lateral resolution was tested on synthetic velocity models constructed by perturbing the preferred starting velocity model for inversion with laterally alternating positive and negative velocity anomalies (Figure 5). The superimposed lateral velocity anomalies were spatially constrained only to the igneous crust (layers $2 \mathrm{~A}$ and $2 \mathrm{~B}$ ), and varied sinusoidally with a peak/trough amplitude of $\pm 0.5 \mathrm{~km} / \mathrm{s}$. The width of the anomalies (half wavelength of sinusoids) varied from $10 \mathrm{~km}$ to $2.5 \mathrm{~km}$. Ray tracing through the constructed synthetic velocity model was performed using the same experimental geometry as for our seismic profiling. The resulting traveltimes were inverted using the same parameters as were used when computing our preferred tomographic models. The recovered synthetic velocity anomalies (Figure 5) were computed as the difference between the inverted and the preferred starting velocity models. The results show that anomalies in layer $2 \mathrm{~B}$ are better resolved than those in layer $2 \mathrm{~A}$, likely because all refracted rays sampled $2 \mathrm{~A}$ but turned in 2B. Furthermore, the magnitudes of the velocity anomalies recovered after inversion are larger than those in the ray traced synthetic model. This illustrates the importance of having good constraints on layer 2A velocities since the inversion cannot effectively adjust incorrect layer $2 \mathrm{~A}$ velocities. Overall, $5 \mathrm{~km}$ wide anomalies were well resolved across the model while $2.5 \mathrm{~km}$ wide anomalies were only resolved on sections of the ridge flanks with little relief, but not in the near axis region (Figure 5).

[24] In addition to ray tracing through multiple starting velocity models to determine which provides the best initial fit to the data, the preferred starting velocity model was altered to determine what effects different starting models would have on the final inverted models. For example, in one test the thickness of layer $2 \mathrm{~A}$ was reduced by $20 \%$. 

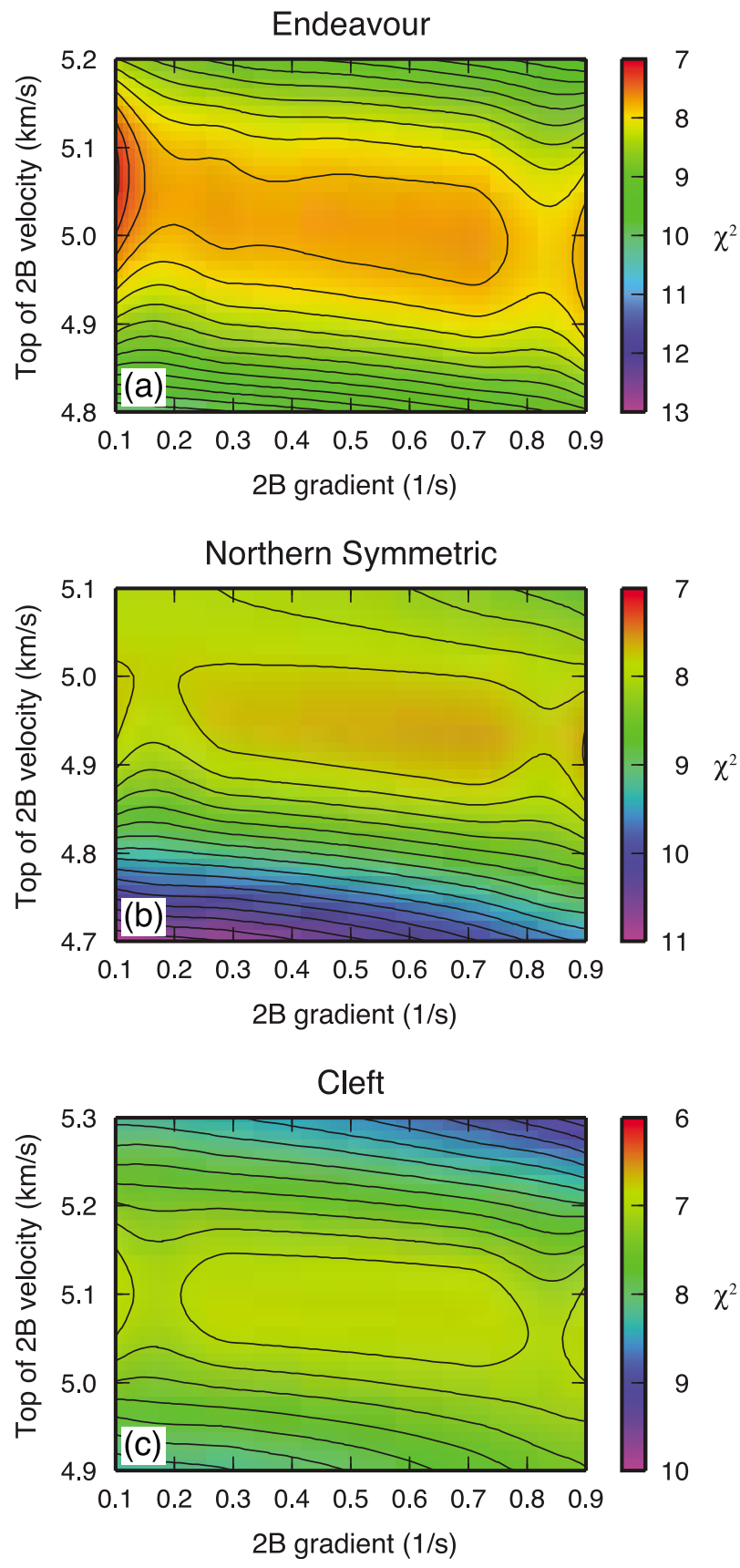

Figure 4. Determination of the best starting velocity model for tomographic inversion of seismic profiles. Chi-square for the (a) Endeavour, (b) Northern Symmetric, and (c) Cleft transects is plotted in color as a function of the velocity at the top of layer $2 \mathrm{~B}$ and the velocity gradient through layer $2 \mathrm{~B}$. Contour interval is 0.2 . The plots show that for all seismic transects the best starting velocity model is more dependent on the velocity at the top of $2 \mathrm{~B}$ and is not greatly affected by the $2 \mathrm{~B}$ velocity gradient. Chi-square was computed as $\chi^{2}=\left(\sum_{i=1}^{n}\left(\left(o_{i}-m_{i}\right) / \Delta o_{i}\right)^{2} / n\right.$, where $o$ is observed traveltime, $m$ is modeled traveltime, $\Delta o$ is uncertainty in the observed traveltime, and $n$ is the number of observations.
This resulted in top of 2B velocities that are slower than those produced using our preferred starting model, with the average layer $2 \mathrm{~B}$ velocity reduced by $0.3 \mathrm{~km} / \mathrm{s}$. There is also some correlation between layer 2A thickness and the inversion's sensitivity to changes in $2 \mathrm{~A}$ thickness such that the greatest difference in top of layer $2 \mathrm{~B}$ velocities occurs where layer $2 \mathrm{~A}$ is thickest. This is likely due to layer $2 \mathrm{~A}$ thickness being reduced most at locations where layer $2 \mathrm{~A}$ is thickest. We also performed the inversion using starting model gradients of 0.1 and $0.9 \mathrm{~s}^{-1}$ to determine how our choice of using a velocity gradient of $0.5 \mathrm{~s}^{-1}$ could affect our final models. Model layer 2B velocities differ on average by 0.02 and $0.03 \mathrm{~km} / \mathrm{s}$ with isolated maximum velocity differences of 0.4 and $0.3 \mathrm{~km} / \mathrm{s}$ for starting models with 2B gradients of 0.1 and $0.9 \mathrm{~s}^{-1}$, respectively.

\section{Results}

[25] The final velocity models for layer $2 \mathrm{~B}$ velocity are shown in Figures $6 \mathrm{a}, 7 \mathrm{a}$, and $8 \mathrm{a}$. The uncertainty in the inverted layer $2 \mathrm{~B}$ velocity is $<0.1 \mathrm{~km} / \mathrm{s}$. This is based on the sensitivity study presented in Figure 4, which shows that change of $\sim 0.1 \mathrm{~km} / \mathrm{s}$ in the $2 \mathrm{~B}$ velocity used to evaluate optimal starting velocity models has a significant impact on the computed traveltimes. The $2 \mathrm{~B}$ vertical velocity gradient, however, is not well constrained, as also indicated by plots of chi-square for a series of starting 1-D velocity models (Figure 4 ). The computed velocity perturbations from the starting velocity models are also shown for all three investigated transects (Figures $6 \mathrm{~b}, 7 \mathrm{~b}$, and $8 \mathrm{~b}$ ). Within the igneous crust, the rays sample layer $2 \mathrm{~A}$ and the top of layer $2 \mathrm{~B}$, generally turning in the upper $500 \mathrm{~m}$ of layer 2B (Figure 9). While the inversion was set to freely modify velocities in all layers, velocities within the sediments and layer $2 \mathrm{~A}$ do not vary much from the starting model. This is because the velocities in these layers are known at a regional scale [Nedimović et al., 2008] and are incorporated in the starting velocity models for inversion, and because all of our picks are from rays turning within layer $2 \mathrm{~B}$.

[26] To extract additional interpretive information we computed mean velocities for the upper $200 \mathrm{~m}$ of layer $2 \mathrm{~B}$, an interval equivalent to the cell size of the inversion grid (Figures 6c, 7c, and 8c). The location of the layer $2 \mathrm{~A} / 2 \mathrm{~B}$ boundary for this computation was determined by evaluating 1-D velocity profiles at every lateral grid node. For each profile, a horizon was determined that represented 

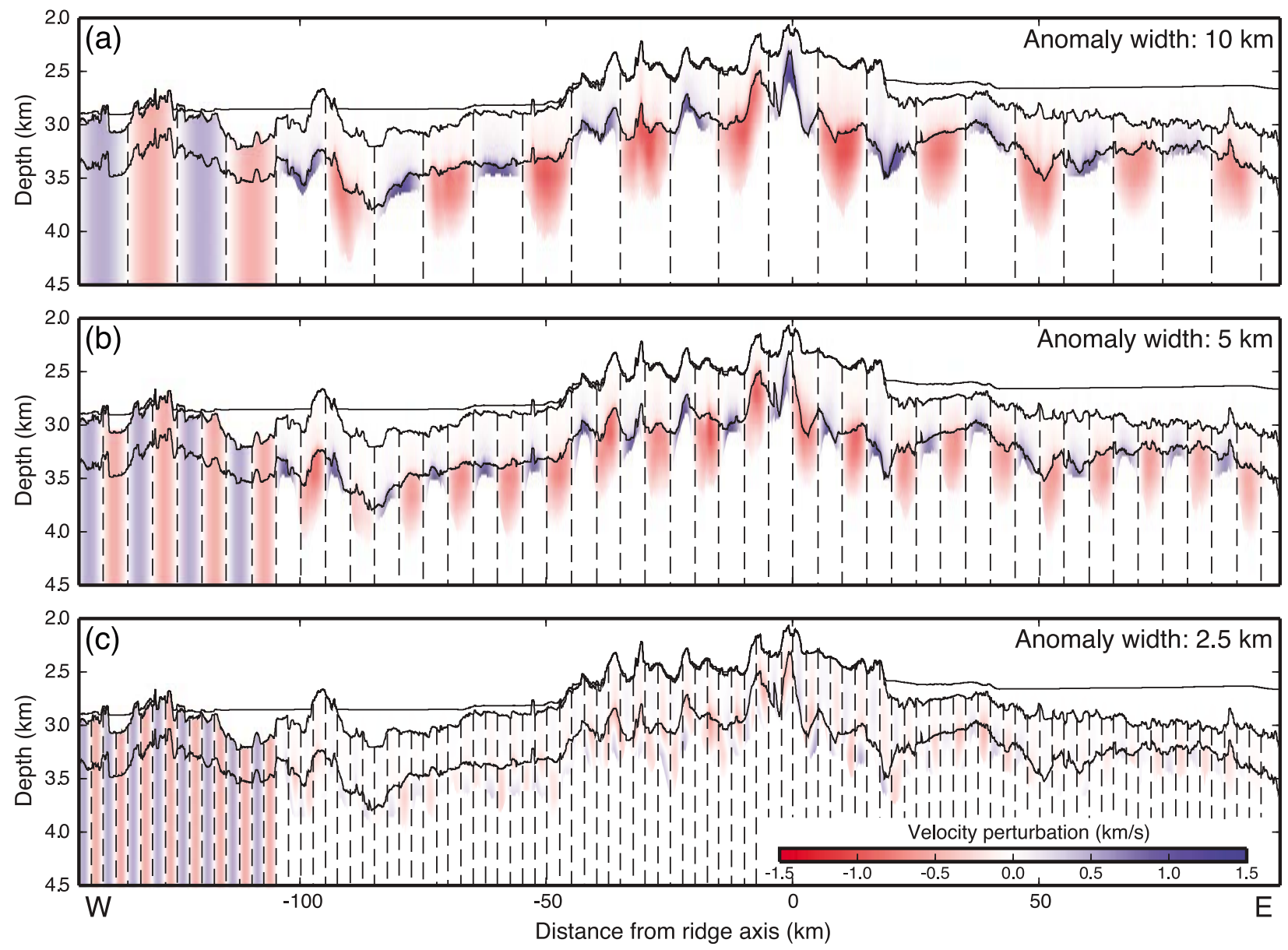

Figure 5. Tomographic resolution tests for the Endeavour transect. Both initial velocity perturbations (left quarter of the profiles) and recovered synthetic velocity anomalies are shown for initial anomaly width of (a) 10, (b) 5, and (c) $2.5 \mathrm{~km}$. Dashed vertical lines indicate the boundaries between initial synthetic anomalies. The seafloor, top of igneous basement, and layer $2 \mathrm{~A} / 2 \mathrm{~B}$ boundary are represented by solid lines. All velocity anomalies (red and blue) are well resolved for the 10 and $5 \mathrm{~km}$ wide cells (Figures $5 \mathrm{a}$ and $5 \mathrm{~b}$, respectively) and are better defined in layer 2B than in layer 2A likely because all refracted rays sampled 2A but turned in 2B. Velocity anomalies for the $2.5 \mathrm{~km}$ wide cells (Figure $5 \mathrm{c}$ ) are only partially resolved, mostly in sections of the ridge flanks with little relief.

the depth at a location $80 \%$ of the way through layer $2 \mathrm{~A}$ in the starting model. The depth of layer $2 \mathrm{~A} / 2 \mathrm{~B}$ boundary was then selected as the first point below that horizon where the velocity gradient attained a value of less than $4 \mathrm{~s}^{-1}$.

\subsection{Layer 2B Velocity Variations}

[27] We observe a range of layer $2 \mathrm{~B}$ velocities across the models from about 4 to about $6 \mathrm{~km} / \mathrm{s}$ (Figures $6 \mathrm{a}, 7 \mathrm{a}$, and $8 \mathrm{a}$ ). Analysis of our results suggests no systematic $2 \mathrm{~B}$ velocity variation with age, except in the vicinity of the ridge axes. The axial region is also characterized by the largest perturbations from the starting velocity models (Figures 6b, 7b, and 8b). While there do not appear to be definitive trends in the velocity anomalies as crust ages beyond the axial region, velocity lows are more likely to be associated with basement highs and velocity highs are more likely to be associated with basement lows.

[28] The lowest velocities for the Endeavour and Northern Symmetric segments occur at the ridge axis. The Cleft segment also displays a local minimum that approximately coincides with the location of the axial region, but that minimum is not as pronounced as the ridge axis minima on the Endeavour and Northern Symmetric segments. The lowest layer 2B velocities at the Cleft transect occur in $\sim 3$ Myr old crust, where this profile crosses a propagator wake. 

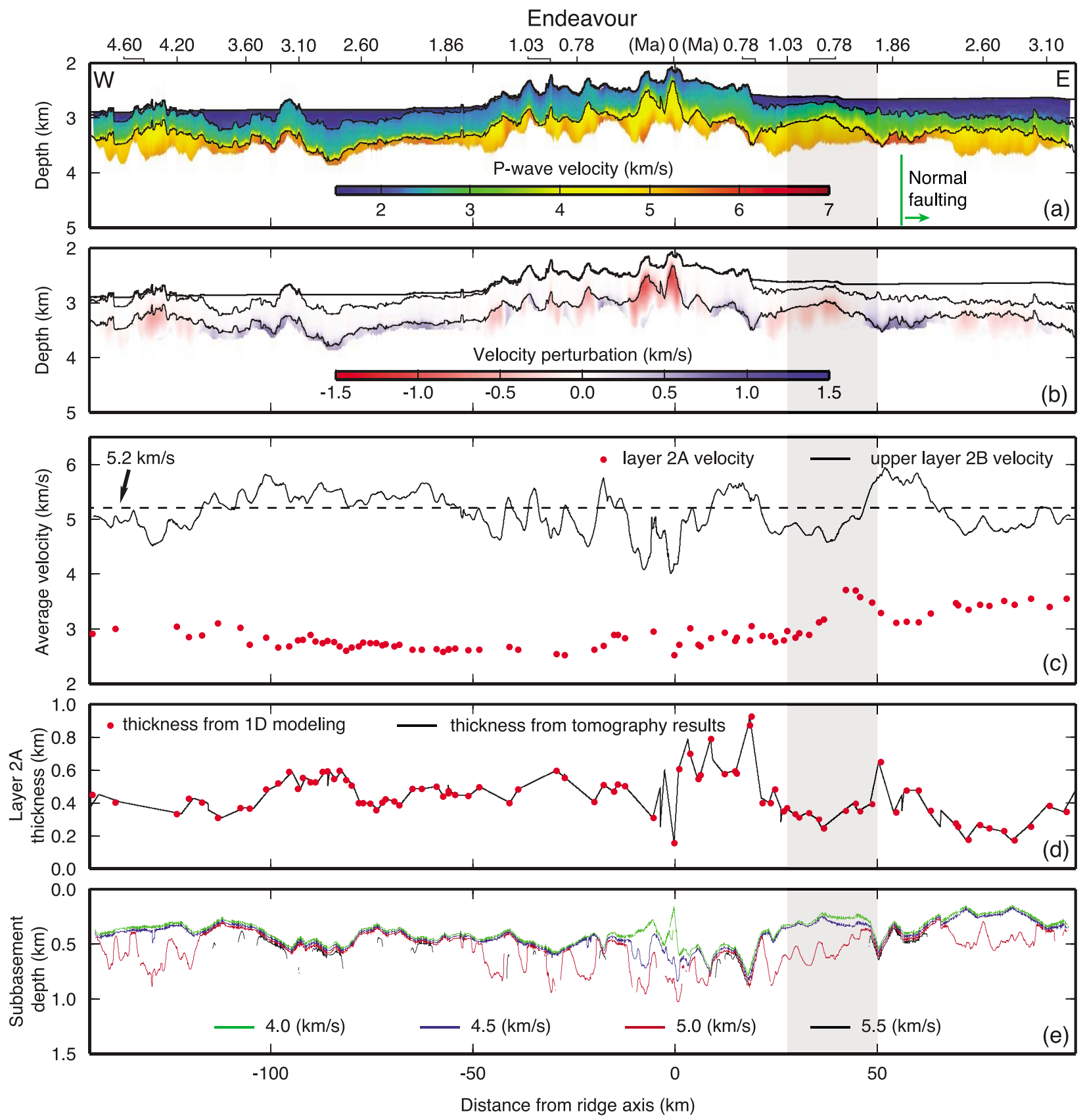

Figure 6. Results for Endeavour transect. (a) Velocity model resulting from traveltime tomographic inversion of layer 2B refraction arrivals. The seafloor, top of igneous basement, and layer $2 \mathrm{~A} / 2 \mathrm{~B}$ boundary are denoted by solid black lines. Onset of normal faulting is shown with a green line and an arrow pointing in the direction of the faulted area. (b) Velocity perturbation from the starting model. (c) Average velocity for the upper $200 \mathrm{~m}$ of layer $2 \mathrm{~B}$ from this 2-D tomographic study and layer 2A average velocity from 1-D traveltime modeling of Nedimović et al. [2008]. (d) Layer 2A thickness from both this 2-D tomographic study and 1-D traveltime modeling of Nedimović et al. [2008]. (e) Crustal thickness to the 4.0, 4.5, 5.0, and $5.5 \mathrm{~km} / \mathrm{s}$ isovelocity lines. The locations of propagator wakes are indicated by the shaded area.

[29] To further analyze inverted layer 2B velocities, we define the velocity of the uppermost layer $2 \mathrm{~B}$ as the average velocity in the upper $200 \mathrm{~m}$ of the layer and compute it for mature crust along all transects excluding regions younger than $1 \mathrm{Ma}$ and regions containing propagator wakes. Although upper layer 2B velocities show significant variation locally (Figures 6a, 7a, and 8a), the average upper layer 2B 

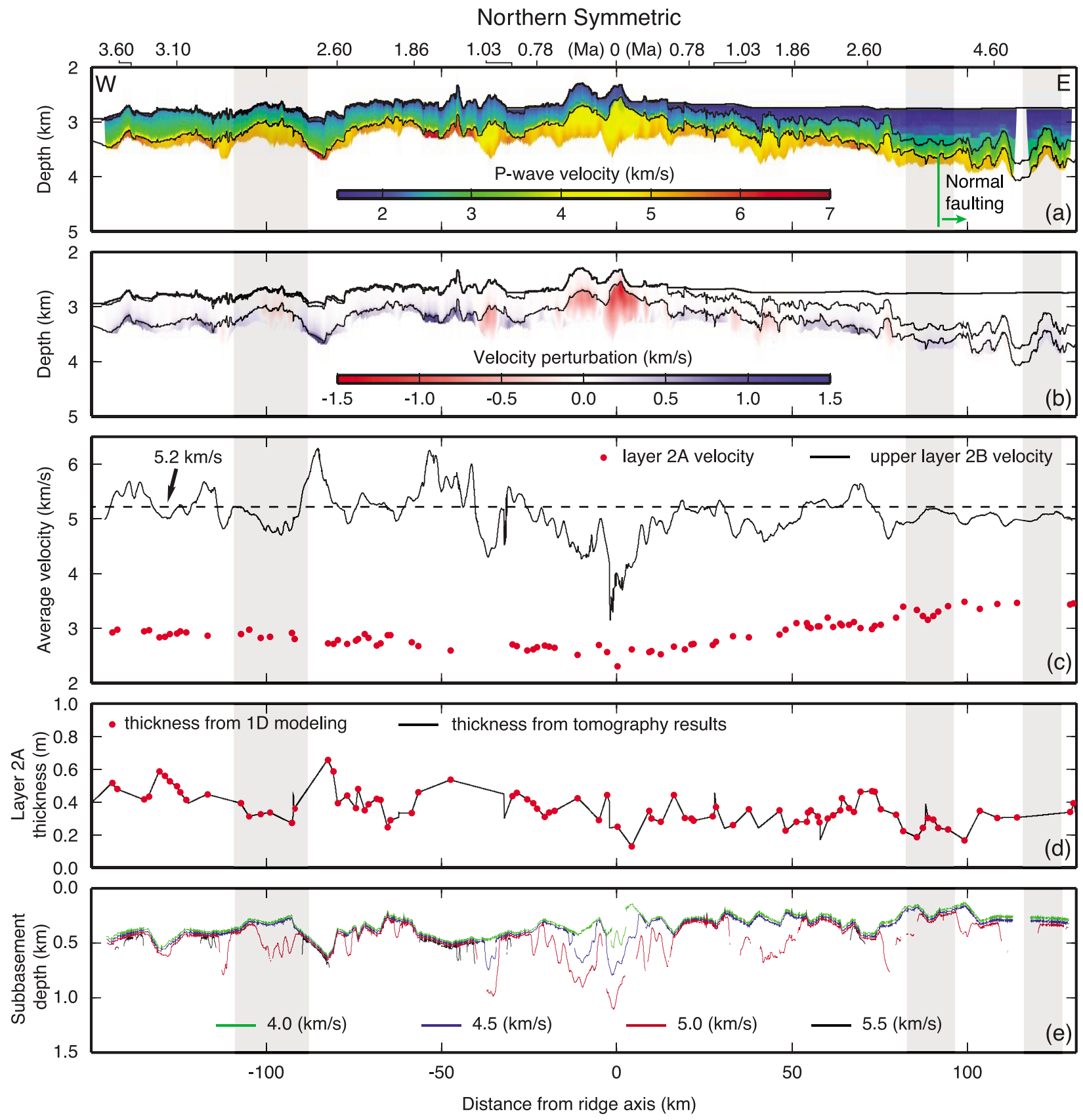

Figure 7. Results for Northern Symmetric transect. Conventions are the same as in Figure 6.

velocities for the six ridge flanks investigated are remarkably similar (Table 1), ranging from 5.0 to $5.3 \mathrm{~km} / \mathrm{s}$. The inclusion of regions younger than $1 \mathrm{Ma}$ and those containing propagator wakes has little effect on the computed average velocities in Table 1. Given our data, we define the overall average mature oceanic crust upper layer 2B velocity as $5.2 \pm 0.3 \mathrm{~km} / \mathrm{s}$. This velocity is reached by about $0.4 \pm 0.1,0.7 \pm 0.1$ and $0.4 \pm 0.1 \mathrm{Ma}$ for the Endeavour, Northern Symmetric and Cleft ridge segments (Figure 10), respectively.

\subsection{Velocity Variations as a Function of Crustal Age}

[30] Upper layer 2B velocities plotted as a function of crustal age show similarities across both flanks for all three segments (Figure 10). Some large velocity excursions occur (e.g., at $\sim 1.5 \mathrm{Ma}$ for Northern Symmetric and at $\sim 4$ Ma for Cleft), but these are in areas with large differences in basement topography between the two flanks. The correlation of velocities as a function of crustal age 

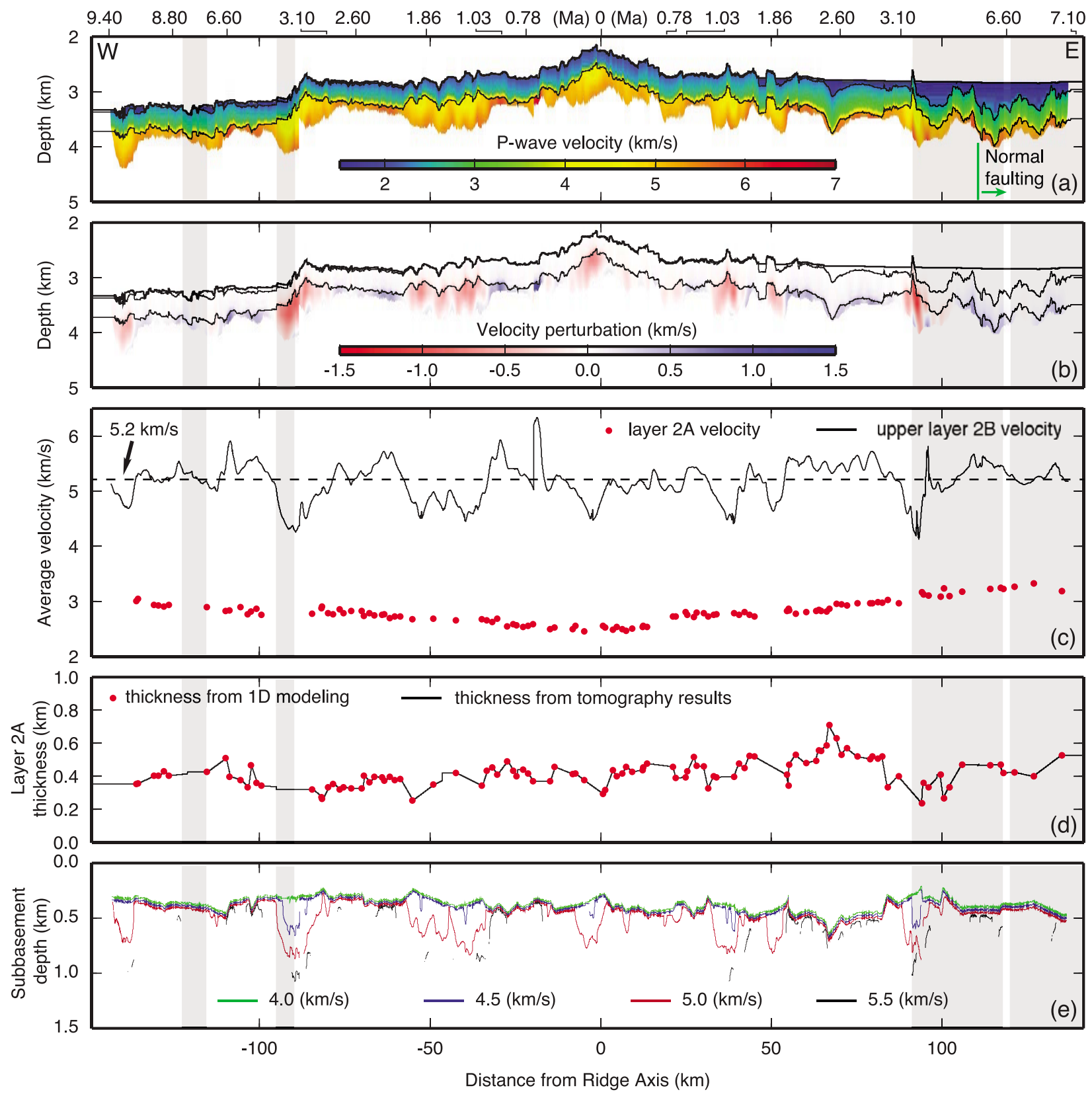

Figure 8. Results for Cleft transect. Conventions are the same as in Figure 6.

between the eastern and western flanks is less robust on the Endeavour segment (Figure 10a).

[31] We performed standard Blackman and Tukey [1958] cross-spectral analysis to quantify the length scales over which upper layer $2 \mathrm{~B}$ velocities as a function of age vary similarly across the two flanks of each of the axis segments. We computed the parametric cospectrum as presented by Jenkins and Watts [1968], Priestley [1981], and Percival and Walden [1993] for the ridge flank pairs. The length of all the time series were limited to the first 2.6 Myr to avoid most of the areas where the signal has been stretched and compressed due to interactions with propagator wakes. A five-point running mean was applied to the spectra to achieve window closing. While this time interval limits our ability to resolve the statistical significance of the lowest frequencies, the spectra still yield insight into the length scale characteristics of ridge axis symmetry. The cospectrum is a measure of 

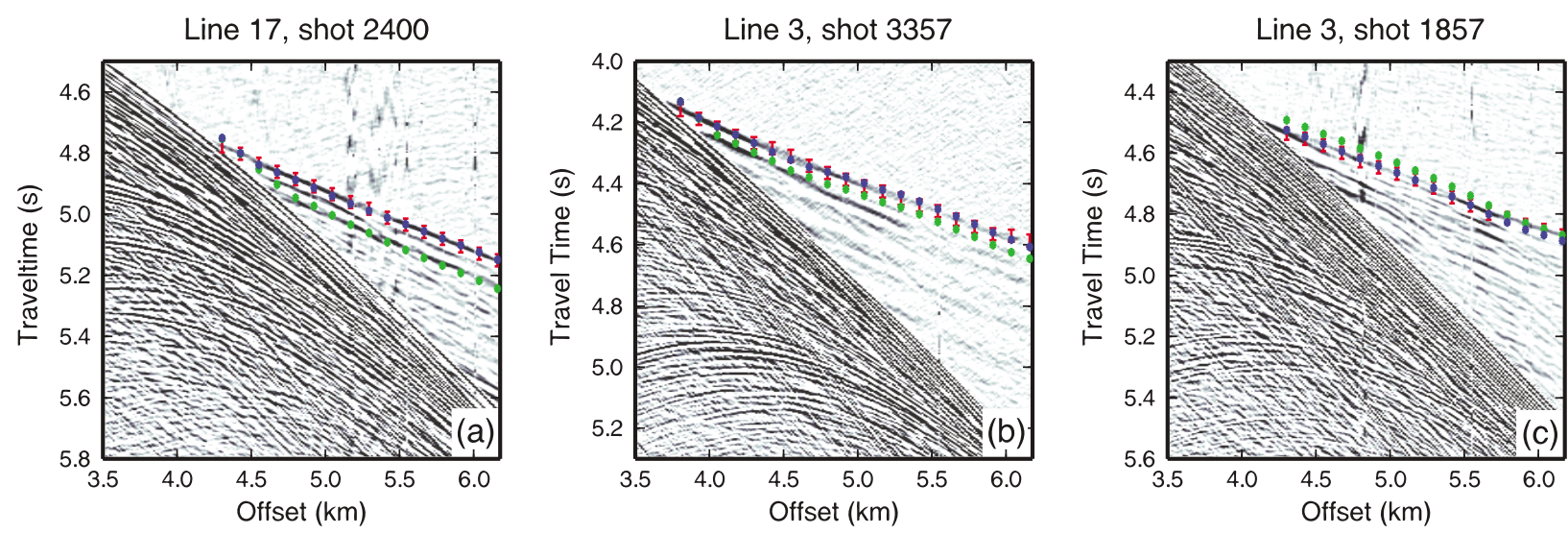

I Observed traveltime

Traveltime predicted by initial model

Traveltime predicted by final model
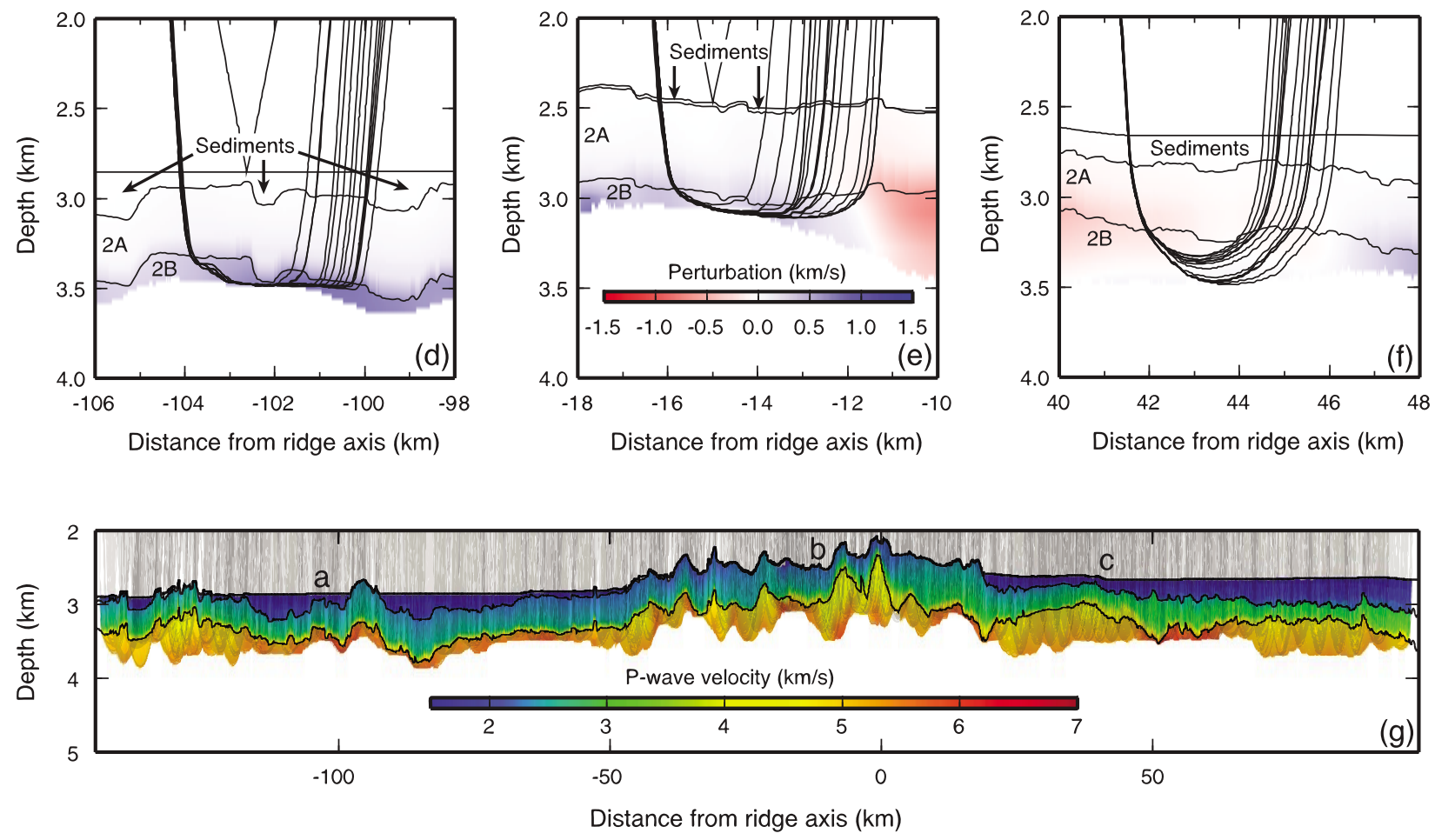

Figure 9. (a-c) Observed and predicted traveltimes of layer 2B refracted arrivals for the example shot gathers from Figure 2 are shown together with $(\mathrm{d}-\mathrm{f})$ the corresponding raypaths and $(\mathrm{g})$ the complete ray coverage for the Endeavour transect. In Figures 9a-9c, observed traveltimes and assigned uncertainty are shown with red error bars. Traveltimes predicted by the initial and final velocity models are represented by blue and green dots, respectively. In Figures $9 \mathrm{~d}-9 \mathrm{f}$, rays (black lines), shown superimposed on the final velocity perturbation model, are sampling the water column, sediments, layer 2A, and layer 2B but turn only in 2B. Only the picked arrival with the shortest offset is modeled as a seafloor reflection. In Figure 9g, full ray coverage (gray lines), superimposed over the final velocity model in color, shows dense sampling of the upper oceanic crust up to a depth of about $500 \mathrm{~m}$ below the layer $2 \mathrm{~A} / 2 \mathrm{~B}$ boundary.

the covariance of the in-phase components of the time series. Our computed cospectra indicate that the majority of the coherent signal lies within the frequency range that corresponds to wavelengths greater than $0.5 \mathrm{Myr}$ (Figure 11). For the Northern Symmetric and Cleft segments, signals from higher-frequency ranges contribute to the total covariance, trending toward no contribu- 
Table 1. Average Velocity of the Uppermost $200 \mathrm{~m}$ of Layer 2B for the Investigated Transects ${ }^{\mathrm{a}}$

\begin{tabular}{lcc}
\hline & $\begin{array}{c}\text { Average } \\
\text { Upper 2B } \\
\text { Velocity (km/s), } \\
\text { West Flank }\end{array}$ & $\begin{array}{c}\text { Average } \\
\text { Upper 2B } \\
\text { Velocity (km/s), } \\
\text { East Flank }\end{array}$ \\
\hline Endeavour & $5.2 \pm 0.3$ & $5.2 \pm 0.4$ \\
Northern Symmetric & $5.4 \pm 0.4$ & $5.0 \pm 0.2$ \\
Cleft & $5.1 \pm 0.4$ & $5.2 \pm 0.3$ \\
\hline
\end{tabular}

${ }^{\mathrm{a}}$ Regions younger than $1 \mathrm{Ma}$ and regions containing propagator wakes were excluded in the computation. Presented errors are standard deviations. Corresponding standard errors are very small because of the large number of samples forming the averages.

tion at frequencies corresponding to wavelengths of $0.26 \mathrm{Myr}$ and $0.33 \mathrm{Myr}$, respectively.

\section{Discussion}

\subsection{Layer 2B Evolution}

[32] Computed tomographic velocities (Figures 6a, $6 \mathrm{c}, 7 \mathrm{a}, 7 \mathrm{c}, 8 \mathrm{a}$, and $8 \mathrm{c}$ ) show that layer $2 \mathrm{~B}$ does not evolve in the same manner as layer $2 \mathrm{~A}$. In the Endeavour, Northern Symmetric and Cleft segments, 2A velocities gradually increase with distance from the ridge axis with slightly more rapid evolution at the ridge axis and do not reach mature oceanic crust values of $\sim 4.3 \mathrm{~km} / \mathrm{s}$ over the sampled crustal age interval from 0 to 5-9 Ma [Nedimović et al., 2008]. Layer 2B velocities do not follow this trend. Instead, uppermost layer $2 \mathrm{~B}$ velocities of $\sim 5.2 \mathrm{~km} / \mathrm{s}$, which we define as mature oceanic crust, are, on average, reached within $\sim 0.5 \mathrm{Myr}$ of crustal formation, suggesting that either layer $2 \mathrm{~B}$ evolution is rapid and not coupled to that of layer $2 \mathrm{~A}$ or that near-axis alteration processes are similar for layers $2 \mathrm{~A}$ and $2 \mathrm{~B}$ but have a different impact on the two layers. Rapid evolution of layer $2 \mathrm{~B}$, interpreted here from tomography results, is supported by compliance measurements from the northern East Pacific Rise [Crawford et al., 1999]. Compliance measurements point to a significant increase in layer $2 \mathrm{~B} \mathrm{Vs} / \mathrm{Vp}$ ratio within $\sim 10 \mathrm{~km}$ from the ridge axis, which is believed to be caused by a drop in porosity due to crack closure.

[33] Earlier OBS investigation of the Endeavour ridge, the SEISRIDG 85 experiment, resulted in top of layer 2B average velocity of $4.8 \mathrm{~km} / \mathrm{s}$ [Cudrak and Clowes, 1993]. This is similar to the average top of $2 \mathrm{~B}$ velocity of $5.0 \pm 0.3 \mathrm{~km} / \mathrm{s}$ obtained in this study for the crustal ages from 0 to $1 \mathrm{Ma}$ covered by the SEISRIDG 85 experiment.
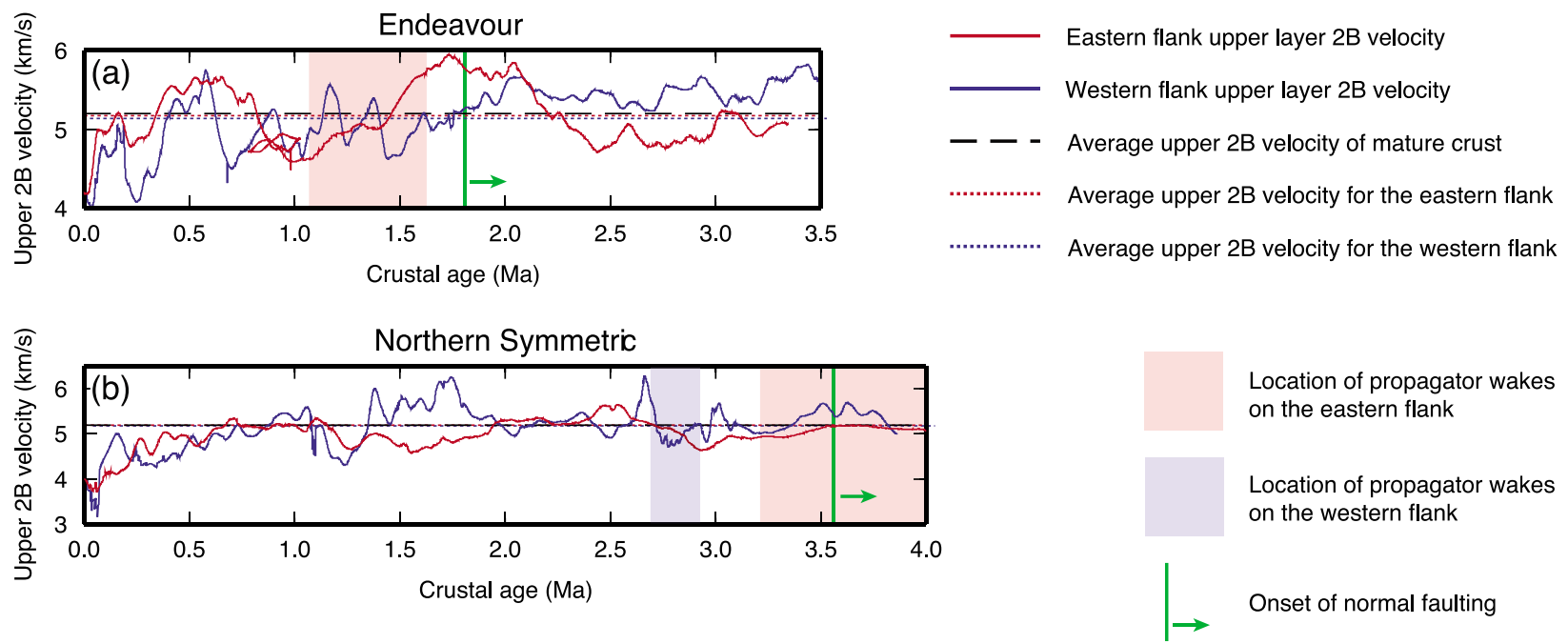

Location of propagator wakes on the eastern flank

Location of propagator wakes on the western flank

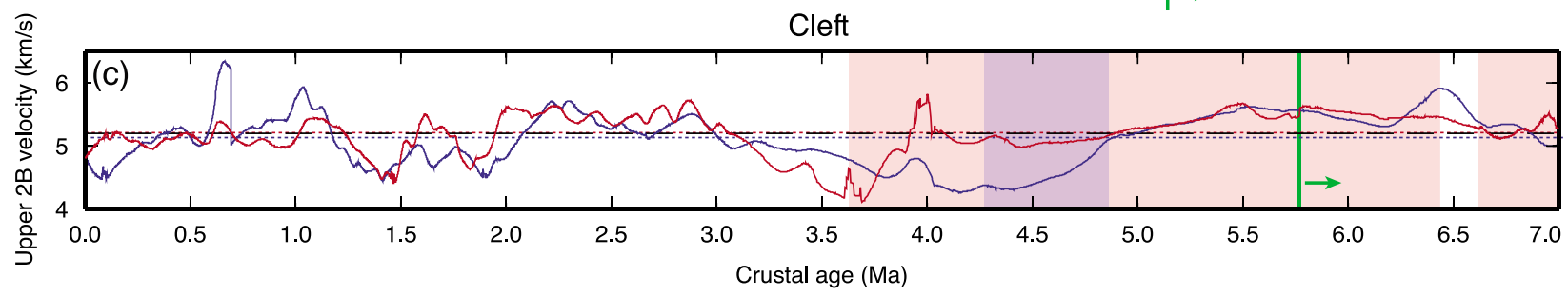

Figure 10. Average upper 2B velocity as a function of crustal age. Blue denotes the western flank of the ridge, and red denotes the eastern. Corresponding dashed lines show the average velocity for each flank. 


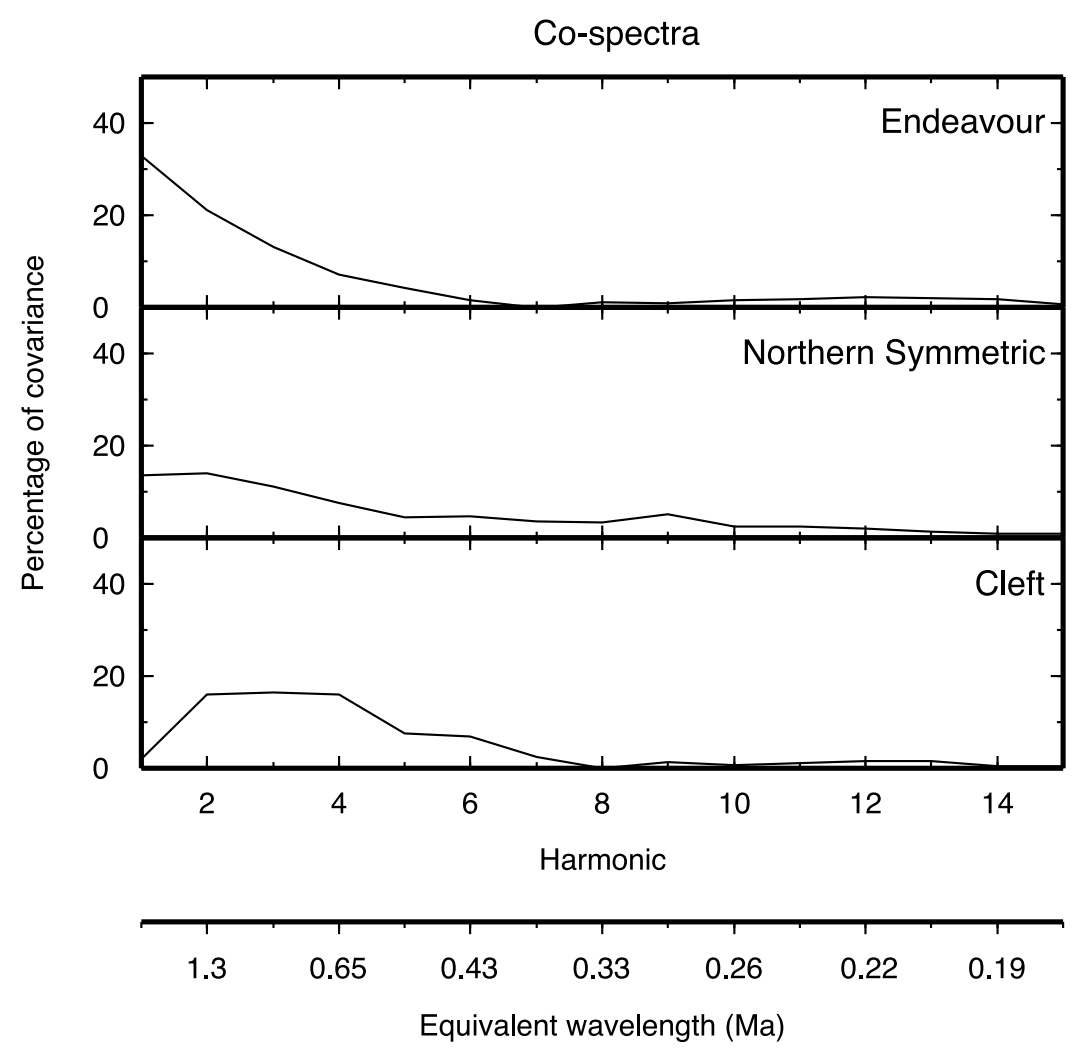

Figure 11. Quantifying the degree of similarity of upper 2B velocity as a function of crustal age for corresponding flanks on each of the investigated ridge segments. Cospectra, which indicate the amount of covariance between the in-phase components of the signals, are plotted as percentage of total covariance for each ridge segment with three-point running mean smoothing.

[34] The only 2-D seismic investigations away from the Juan de Fuca Ridge designed to, at least in part, target layer 2B evolution are an OBS study of the southern East Pacific Rise by Grevemeyer et al. [1998] and a multichannel seismic study of the Southeast Indian Ridge by Baran et al. [2010]. Unfortunately, the Grevemeyer et al. [1998] experiment does not capture the rapid evolution of layer $2 \mathrm{~B}$ with crustal age because it consists of a number of ridge-parallel profiles, where the profiles cross crust from 0.5 to $8.3 \mathrm{Myr}$ ago and the Baran et al. [2010] study samples crust with a maximum age of $0.55 \mathrm{Ma}$ and thus does not give constraints on the age at which layer $2 \mathrm{~B}$ ceases to evolve.

[35] It is widely thought that the evolution of layer $2 \mathrm{~A}$ is related to the precipitation of hydrothermal minerals that fill in cracks in the porous basalt section [Jacobson, 1992]. The lack of observed evolution in layer $2 \mathrm{~B}$ past $\sim 0.5 \mathrm{Ma}$ suggests that the "passive" hydrothermal circulation driving 2A evolution, described by Jacobson [1992], does not extend into or has less of an effect on $2 \mathrm{~B}$, but that the "active" hydrothermal circulation centered about the ridge crest and extending down to the magma chamber may have a role in early $2 \mathrm{~B}$ evolution. This is particularly plausible because the $0.8 \mathrm{~km} / \mathrm{s}$ increase in average velocity of the topmost section of layer $2 \mathrm{~B}$ in the first 0.5 Myr after crustal formation is much larger than the velocity increase of $0.2 \mathrm{~km} / \mathrm{s}$ that can be attributed to the cooling of the dike section alone (assuming a temperature decrease of $500^{\circ} \mathrm{C}$ to $0^{\circ} \mathrm{C}$ ) [Christensen, 1979] or to the increase in 2B velocities due to increasing overburden pressures and associated crack closure with thickening of $2 \mathrm{~A}$. The $0.8 \mathrm{~km} / \mathrm{s}$ increase in the average uppermost layer 2B velocity was computed by averaging the layer $2 \mathrm{~B}$ velocity for the axial region $(4.4 \pm 0.3 \mathrm{~km} / \mathrm{s}$, see Table 2) and subtracting it from $5.2 \mathrm{~km} / \mathrm{s}$, the computed uppermost $2 \mathrm{~B}$ velocity characteristic of mature oceanic crust in this region.

[36] Rohr [1994] and Nedimović et al. [2008] observed that the amount of subsequent sediment burial affects velocities in layer $2 \mathrm{~A}$, but our results for layer $2 \mathrm{~B}$ do not follow this trend. The similarities in $2 \mathrm{~B}$ velocities with age between the flanks of 
Table 2. Average Velocity of the Uppermost $200 \mathrm{~m}$ of Layer 2B for the Axial Region Covering Crustal Ages From 0 to $0.1 \mathrm{Ma}^{\mathrm{a}}$

\begin{tabular}{lc}
\hline & $\begin{array}{c}\text { Average } \\
\text { Axial Upper 2B } \\
\text { Velocity }(\mathrm{km} / \mathrm{s})\end{array}$ \\
\hline Endeavour & $4.5 \pm 0.3$ \\
Northern Symmetric & $3.9 \pm 0.3$ \\
Cleft & $4.8 \pm 0.2$ \\
Three axial regions combined & $4.4 \pm 0.3$ \\
\hline
\end{tabular}

${ }^{\mathrm{a}}$ Pelayo et al. [1994] and Stein and Stein [1994]. Presented errors are standard deviations.

the Juan de Fuca Ridge show that present 2B velocities are likely more dependent on processes occurring at and shortly after the time of formation. Porosity and fracturing of basaltic rocks have more of an effect on seismic velocities than their chemical composition [Wilkens et al., 1991; Miller et al., 1996; Swift et al., 2008; Carlson, 2010]. Thus, the variations in $2 \mathrm{~B}$ velocity could be due to either differences in the amount of fracturing acquired at the time of formation, or the subsequent extent of alteration that was able to take place before the crustal column was carried away from the region of "active" hydrothermal circulation. Conversely, the composition of alteration minerals has an effect on rock velocities [Johnston and Christensen, 1997] and thus variations in $2 \mathrm{~B}$ velocity could perhaps be related to the types of precipitated hydrothermal minerals.

\subsection{Patterns and Effects of Hydrothermal Circulation}

[37] Heat flow, MCS, swath bathymetry and water geochemistry data, as well as numerical modeling, can provide information on the patterns of hydrothermal circulation within the oceanic crust [e.g., Williams et al., 1974; Langseth et al., 1988; Wang et al., 1997; Hunter et al., 1999; Fisher et al., 2003]. Insights into the hydrothermal circulation within our study area have been gained for parts of the eastern Endeavour flank [Davis et al., 1992; Hunter et al., 1999; Fisher et al., 2003] and a small section of the western Endeavour flank in the vicinity of the ridge axis [Johnson et al., 1993]. The inferred length scales of hydrothermal cells vary from $\sim 700 \mathrm{~m}$ [Davis et al., 1992] to $>50 \mathrm{~km}$ [Fisher et al., 2003]. Spatially, much of this information has been collected coincident with our Endeavour MCS transect, potentially allowing for a comparison between the inferred hydrothermal circulation patterns and computed layer $2 \mathrm{~B}$ velocities. We focus our analysis on hydrothermal cells wider than
$4 \mathrm{~km}$ because the lateral resolution of our tomographic velocities does not permit a more detailed investigation.

[38] Heat flow profiles crossing the strike of the local crustal structural grain have been repeatedly shown to exhibit systematic high and low anomalies with wavelengths of 4 to $10 \mathrm{~km}$ that correlate well with the igneous basement highs and lows, respectively [e.g., Williams et al., 1974; Langseth et al., 1988; Davis et al., 1992; Johnson et al., 1993]. The high heat flow at basement highs is ascribed to hydrothermal up-flow zones and the low heat flow at basement lows to down-flow zones, suggesting that igneous basement relief has a major impact on the patterns of hydrothermal circulation. Numerical modeling provides further support for basement relief as one of the primary factors influencing hydrothermal flow [Wang et al., 1997].

[39] Further from the ridge axis, field data [Fisher et al., 2003] and modeling [Wang et al., 1997] show that sediment cover limits the crust's interaction with seawater to a point that its spatial coverage and thickness can affect the location of hydrothermal up-flow and down-flow zones and control the direction in which the cells operate. An excellent example is the well documented hydrothermal cell stretching for some $50 \mathrm{~km}$ between a down-flow zone at the Grizzly Bare outcrop located on the eastern Northern Symmetric flank, and an up-flow zone at the Baby Bare outcrop located on the eastern Endeavour flank just north of the eastern end of our Endeavour MCS transect [Fisher et al., 2003]. Here, in an area with thick sediment cover, the pattern of hydrothermal circulation exploits the basement outcrops because fluid exchange with the seawater is easiest at those locations. This yields a convective cell with a wavelength that is much longer than the typical distance between local abyssal hills and troughs.

[40] In a broad sense, two distinct length scales of alternating positive and negative velocities anomalies can also be observed in our tomography models. In the near-axis region where there is little to no sediment, the width of velocity highs and lows, more easily recognized as positive and negative velocity perturbations from the starting model (Figures 6b, $7 \mathrm{~b}$, and $8 \mathrm{~b}$ ), is approximately $5 \mathrm{~km}$. In areas where sediment has covered the abyssal hills and troughs these variations occur over longer length scales, generally $>30 \mathrm{~km}$.

[41] Johnson et al. [1993] investigated the oceanic crust immediately west of the Endeavour ridge and 
found that the local length scale of heat flow anomalies and therefore hydrothermal cells is approximately 7-8 km. Comparison of Johnson et al.'s [1993] observations, which spatially coincide with our Endeavour MCS transect, reveal correlation of both basement highs (inferred up-flow zones) with layer 2B velocity lows and basement lows (inferred down-flow zones) with layer 2B velocity highs (Figure 6a). This indicates that upper layer $2 \mathrm{~B}$ pore space clogging may be occurring in young oceanic crust. The associated mineral precipitation process appears to take place within the time period of active upper layer $2 \mathrm{~B}$ evolution determined in this work to operate in crust aged from 0 to $\sim 0.5 \mathrm{Ma}$. The effect of near axis mineral precipitation on upper layer $2 \mathrm{~B}$ velocities is expected to be similar on both flanks because the distribution of abyssal hills, and thus near axis up-flow and down-flow zones, is likely to be symmetric within the vicinity of the ridge axis.

[42] The observed correlation in young oceanic crust of both basement highs (inferred up-flow zones) with layer $2 \mathrm{~B}$ velocity lows and basement lows (inferred down-flow zones) with layer 2B velocity highs is in agreement with earlier studies [e.g., Bischoff and Seyfried, 1978; Sleep, 1991] on anhydrate precipitation from seawater. Bischoff and Seyfried [1978] ran experiments that predict large precipitation of anhydrate from seawater within a high-temperature $\left(>150^{\circ} \mathrm{C}\right)$ alteration regime found in the axial/near axial region that is sufficient to clog all pore space and strongly inhibit seawater circulation. Sleep's [1991] numerical thermal modeling further suggests that anhydrate precipitates in the axial/near axial region at the base of downwelling circulation models, within the sheeted dike complex. Pore clogging in the sheeted dike complex would significantly increase seismic velocity of layer $2 \mathrm{~B}$, as observed in the tomographic sections presented in this work. However, the two holes drilled into the sheeted dike complex, holes 504B and 1256D, do not support the hypothesis on significant precipitation of anhydrate within the sheeted dike complex of the young oceanic crust. Minor amount of anhydrate is found in the cores drilled in oceanic crust at ODP Hole 504B [Teagle et al., 1998]. In ODP Hole 1256D, anhydrite is more abundant in the lava-dike transition and in the upper dikes, as would be expected from numerical modeling [Sleep, 1991] and seismic tomography results from this study, but still present in much lower quantities than predicted by numerical models of hydrothermal circulation [Wilson et al., 2006]. Additional drilling into the sheeted dike complex and improved core recovery is needed to resolve the conundrum resulting from the large amount of precipitated anhydrite predicted or inferred from geochemical, numerical and seismic studies, and the relatively small amount of anhydrate found in holes 504B and 1256D.

[43] Along our MCS transect we identify pairs of isolated basement highs separated by sedimentary minibasins that may be guiding hydrothermal discharge and recharge in the older crust. One example pair is located on the Endeavour transect $\sim 95$ and $125 \mathrm{~km}$ west of the ridge axis, where the sediments are moderately thick and continuous (Figures 6 and 12a); the other is on the Northern Symmetric transect $\sim 35$ and $45 \mathrm{~km}$ west of the ridge axis, where sedimentary cover is thin and discontinuous (Figures 7 and 12b). These two pairs of basement highs differ from each other and from the pair described by Fisher et al. [2003] in the distance between potential up-flow and down-flow locations and in the distribution and thickness of sediment cover that overlies the basement, possibly giving insight to how sediment cover affects the length of hydrothermal cells. Generally, for the length scales we can study, it appears that the size of the hydrothermal cells is proportional to the thickness and continuity of sedimentary cover.

[44] A 2B velocity high and low centered below basement outcrops characterizes both pairs of basement highs discussed (Figures 6, 7, 12a, and $12 \mathrm{~b}$ ), potentially suggesting that one high could be a zone of downwelling and the other a zone of upwelling. We further speculate that in older crust sediment accumulations not only increase the hydrothermal cell wavelengths but also reorganize them so that some of the basement high discharge (upflow) zones perhaps develop into recharge (downflow) zones.

[45] Our speculations are supported by the multidisciplinary data collected over a section of the eastern Endeavour flank affected by sedimentation. Heat flow [Davis et al., 1992], direct fluid flow and pore fluid geochemistry [Hunter et al., 1999] data suggest a hydrothermal cell extending for some $30 \mathrm{~km}$, with down-flow and up-flow zones at $\sim 15$ and $\sim 45 \mathrm{~km}$ east of the ridge axis, respectively. The coincident reflection and tomographic velocity images (Figure 12c) show that the outcropping basement high (inferred down-flow zone) is characterized by high upper 2B velocities, and that the thinly sedimented basement high (inferred up-flow zone) is characterized by low $2 \mathrm{~B}$ velocities. If the upper crustal velocity patterns found in hydrother- 

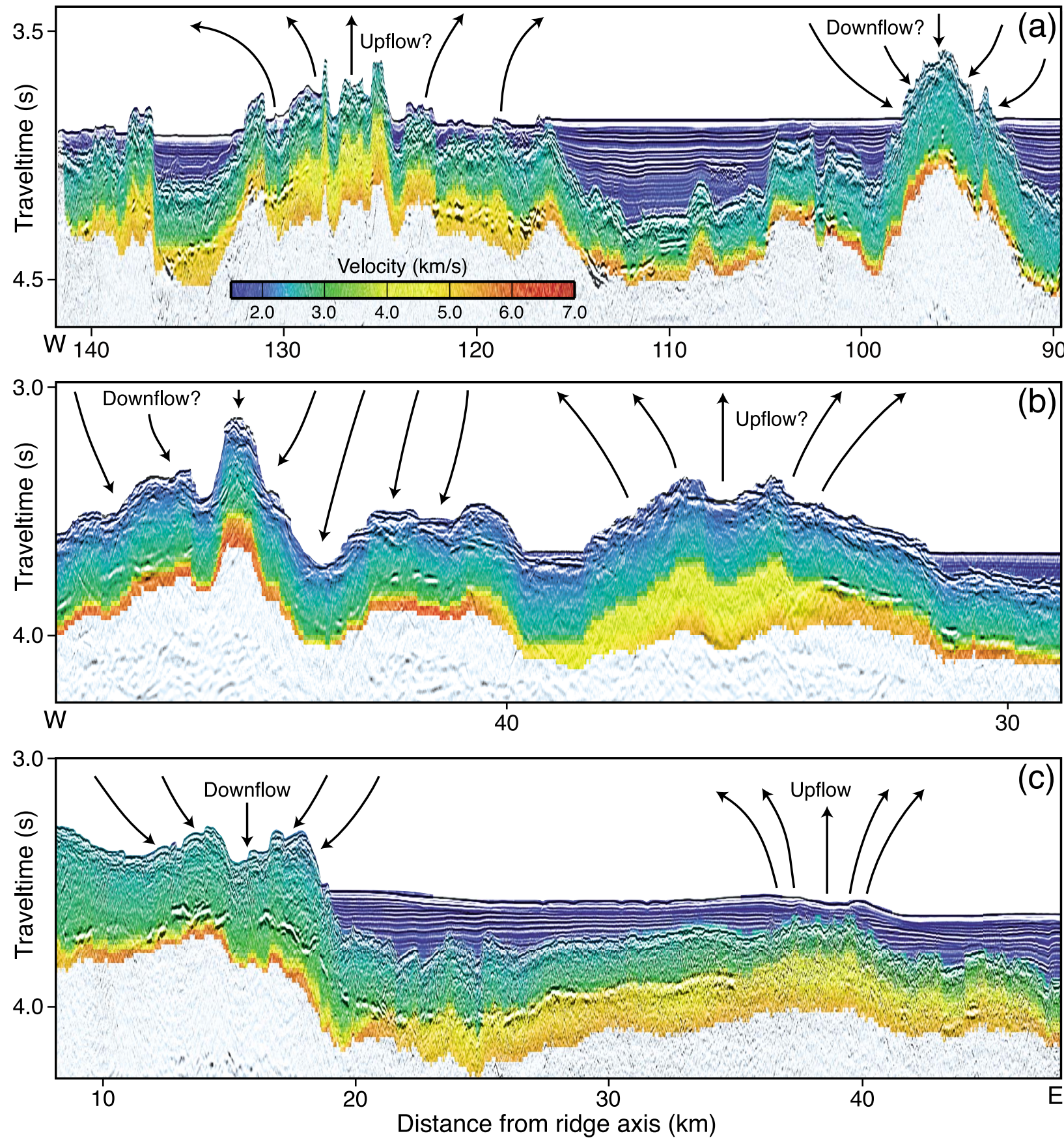

Figure 12. Composite seismic reflection and $\mathrm{P}$ wave tomography images of three pairs of basement highs separated by sedimentary minibasins that may be guiding hydrothermal discharge and recharge in the study area. The three examples shown are from (a) western Endeavour flank, (b) western Northern Symmetric flank, and (c) eastern Endeavour flank. Arrows mark the inferred (Figures 12a and 12b) or measured (Figure 12c) up-flow and down-flow zones.

mal cell shown in Figure 12c are characteristic of sedimented oceanic crust, then the layer $2 \mathrm{~B}$ velocity high and low centered below basement outcrops shown in Figures 12a and 12b can be interpreted as hydrothermal recharge and discharge zones, respectively. For the low-temperature $\left(<150^{\circ} \mathrm{C}\right)$ alteration regime that operates in the off-axis oceanic crust this suggests one or more of the following: (1) greater mineral precipitation in layer $2 \mathrm{~B}$ in the down-flow zones, (2) greater inherited porosity in the up-flow arms of hydrothermal cells, and 
(3) dissolution of precipitated layer 2B minerals in the up-flow zones.

[46] The eastern flank of the Juan de Fuca Ridge is more affected by sedimentation and should, on average, be more affected by the conversion of down-flow zones to up-flow zones as increasing sediment cover makes basement lows less convenient locations for fluids to enter the igneous crust. Consequently, the average mature upper layer 2B velocity on the western flank could be somewhat higher than on the eastern flank because of the relatively larger number of down-flow zones enhancing layer 2B maturation in crust older than $0.5 \mathrm{Ma}$. Computed mature upper layer 2B velocities are on average only slightly higher on the western flank $(0.1 \mathrm{~km} / \mathrm{s}$; Table 1) because the down-flow footprint likely covers only a small portion of the igneous basement.

\subsection{Layer 2B Velocity and Geologic Processes}

[47] Several geologic processes can affect the velocity of the upper oceanic crust as it ages including precipitation of low-temperature alteration minerals, ridge propagation, hot spot volcanism, faulting, and cracking due to hydrothermally driven cooling. Overall these geologic processes tend to affect the ridge flanks asymmetrically, overprinting the inherited velocity structure, and reducing the layer 2B velocity correlation between flanks. Distinguishing the effects of a particular geologic process on layer $2 \mathrm{~B}$ velocity from the effects of other processes is challenging as in most cases the areas affected by various processes overlap spatially.

\subsubsection{Quantifying the Limit of Crustal Accretion Symmetry}

[48] Oceanic crustal generation takes place in the axial region, where, over a broad scale, both ridge flanks are similarly accreted. Assuming there are no other magmatic or tectonic processes affecting the oceanic crust after it is created, noticeable symmetry of the layer $2 \mathrm{~B}$ velocity structure as a function of crustal age between the corresponding flanks would be expected. Juan de Fuca upper layer $2 \mathrm{~B}$ velocities plotted as a function of crustal age (Figure 10) show such similarities across the investigated ridge flanks.

[49] The cospectrum is the real component of the cross-spectral density function and provides the covariance between the in-phase components across the range of rotational frequencies. When computed for upper layer 2B velocity as a function of crustal age for the pairs of ridge segment flanks, this quantity indicates the frequency ranges and corresponding time scales over which velocities in the two flanks vary similarly as well as which frequencies contribute most to the observed signals. At high frequencies the cospectrum indicates how similar short time period processes are on both sides of the ridge axis. These short time period processes are possibly related to accretion at the ridge axis. Conversely, at frequencies that correspond to longer wavelengths, the cross spectrum yields information about similarities in the broader trends in the history of the ridge flanks. If crustal accretion and evolution are similar on both flanks, we would expect highs in the cospectrum at long wavelengths and lows at shorter wavelengths where near-axis processes might not be exactly identical on both sides of the ridge axis.

[50] The cospectra for flank pairs of all three investigated ridge segments (Figure 11) indicate that the main contribution to the velocity correlation is found at long wavelengths $>0.5 \mathrm{Myr}$ with still some contributions at shorter wavelengths for the Northern Symmetric and Cleft segments. It is possible that the signal would extend to these shorter wavelengths in the Endeavour segment as well but much of the short-period energy on the eastern flank was stretched in the conversion from distance from the ridge axis to crustal age due to the presence of the propagator wake. This decay in the cospectra at wavelengths less than $0.5 \mathrm{Myr}$ might indicate the lower limit of the time interval over which accretionary and early evolutionary processes can be expected to yield coherent variations in crustal structure. Below that threshold, each flank acts more independently in producing higher-frequency variations.

\subsubsection{Effect of Propagator Wakes}

[51] In our models (Figures 6a, 7a, and 8a), the location of propagator wakes generally coincides with local minima in upper layer $2 \mathrm{~B}$ velocity. Average top of layer $2 \mathrm{~B}$ velocity over propagator wakes is $5.0 \pm 0.2 \mathrm{~km} / \mathrm{s}$, slightly lower than $5.2 \pm$ $0.3 \mathrm{~km} / \mathrm{s}$ computed for mature oceanic crust. This is the opposite of what appears to occur in layer 2A. Nedimović et al. [2008] observe increased average $2 \mathrm{~A}$ velocities at propagator wakes and attribute this to either increased alteration due to channelized fluid flow or structural differences inherited at the time of crustal accretion. This identified local change in layer $2 \mathrm{~A}$ velocity is characterized by an 
increase in the velocity of the high-gradient, lower layer $2 \mathrm{~A}$ and little change in the low-gradient, upper layer $2 \mathrm{~A}$ velocity.

[52] Large amounts of fracturing occur as ridge tips propagate [Kleinrock and Hey, 1989]. Thus, propagator wakes should be highly fractured areas characterized by increased porosity within both layers $2 \mathrm{~A}$ and $2 \mathrm{~B}$. The reduction in $2 \mathrm{~B}$ velocities observed in our tomography models at propagator wakes can be explained by this increased amount of fracturing. The increased lower $2 \mathrm{~A}$ velocities at propagator wakes are perhaps caused by a different geometry of the pore space in this section of the intrusives that is prone to faster clogging, particularly under focused fluid flow hypothesized by Nedimović et al. [2008]. Alternatively, the focused fluid flow did not extend into layer $2 \mathrm{~B}$ or a different alteration processes operated in the topmost section of the dikes (upper layer 2B) than in the lowermost section of extrusives (lower layer 2A).

\subsubsection{Origin of the Off-Axis Thickening of Layer $2 \mathrm{~A}$}

[53] Some researchers have proposed that the nearaxis thickening of layer $2 \mathrm{~A}$ is the result of the topmost section of layer $2 \mathrm{~B}$ being converted to $2 \mathrm{~A}$ via the downward propagation of the hydrothermally driven cracking front into layer $2 \mathrm{~B}$ [e.g., McClain et al., 1985; Christeson et al., 2007]. Assuming that material accreted at the ridge axis inherits approximately the same velocity structure throughout the life of the ridge, the thickness to velocity contours in layer $2 \mathrm{~B}$ should remain constant or increase with distance from the ridge axis if the cracking front is extending into layer $2 \mathrm{~B}$. The results of our models (Figures 6e, 7e, and 8e) show the opposite with more low-velocity material at the ridge axis than off axis. Furthermore, in areas where velocity contours $>4.5 \mathrm{~km} / \mathrm{s}$ are incorporated in the high-gradient zone of $2 \mathrm{~A}$, the subbasement depth to those contours is less than in areas where those contours lie in $2 \mathrm{~B}$. We would expect these contours to deepen if cracking extended through the existing structure. Thus, we favor the model in which the bulk, if not all of layer 2A thickening is achieved by off-axis emplacement of extrusive material [Toomey et al., 1990; Vera and Diebold, 1994; Hooft et al., 1996; Carbotte et al., 1997].

\subsubsection{Faulting and Layer 2B Velocities}

[54] The coincident MCS reflection study along the transects presented in this paper resulted in the direct imaging of crustal-scale normal faults which are interpreted as pathways for fluid transport and hydration [Nedimović et al., 2009]. Faulted offsets within the sedimentary layering are typically linked to larger offset scarps in the basement topography and suggest that the normal fault systems formed at the spreading center begin to reactivate at distances of up to $\sim 200 \mathrm{~km}$ seaward of the Cascadia trench.

[55] The onset of extensional or transtensional faulting as defined by Nedimović et al. [2009] is shown in Figures 6a, 7a, 8a, and 10 with a green line and arrow. The upper 2B velocities along all three eastern ridge flanks, where the faulting is observed, appear to slightly decrease as the crust ages and becomes more faulted. Laboratory, borehole, refraction and reflection work have shown that faulting generally increases porosity and rock alteration, and as such, usually leads to reduced seismic velocities in the affected area [e.g., Mooney and Ginzburg, 1986]. Therefore, since faulting has been imaged to penetrate to upper mantle depths on the eastern flank of the Juan de Fuca Ridge, we speculate that it not only plays a role in layer $2 \mathrm{~B}$ evolution, but in the evolution of other oceanic crustal layers and uppermost mantle as well.

\section{Conclusions}

[56] Our hydrophone streamer 2-D traveltime tomography along three $\sim 300 \mathrm{~km}$ long MCS transects crossing the Endeavour, Northern Symmetric, and Cleft segments of the Juan de Fuca Ridge has yielded the most extensive and detailed velocity models of the upper section of seismic layer $2 \mathrm{~B}$ to date. Examination of the tomography models and the computed mean velocities for the upper $200 \mathrm{~m}$ of layer 2B gives new insights into the structure and evolution of this seismic layer: (1) Upper layer $2 \mathrm{~B}$ velocities vary from $<4$ to $>6 \mathrm{~km} / \mathrm{s}$ but the average values for the investigated six ridge flanks are remarkably similar ranging from 5.0 to $5.3 \mathrm{~km} / \mathrm{s}$, with velocity lows at the ridge axis $(4.4 \pm 0.3 \mathrm{~km} / \mathrm{s})$ and an overall average mature oceanic crust upper layer $2 \mathrm{~B}$ velocity of $5.2 \pm 0.3 \mathrm{~km} / \mathrm{s}$. (2) The $5.2 \mathrm{~km} / \mathrm{s}$ upper layer $2 \mathrm{~B}$ velocity, characteristic of the mature oceanic crust in this region, is on average reached by $\sim 0.5 \mathrm{Ma}$ of crustal formation marking the most prominent $(\sim 0.8 \mathrm{~km} / \mathrm{s})$ systematic change in layer $2 \mathrm{~B}$ velocities observed. (3) Of the various processes that can affect layer $2 \mathrm{~B}$ as it ages, including precipitation of alteration minerals, ridge propagation, sedimentation, faulting, and cracking due to hydrothermally driven cooling, the strongest impact may be that of 
mineral precipitation due to "active" hydrothermal circulation centered about the ridge crest and driven by the heat from the magma chamber. (4) The rapid evolution of layer $2 \mathrm{~B}$ is vastly different from that of seismic layer 2A, which shows some rapid nearaxis evolution [Nedimović et al. 2008] but appears to be mostly affected by "passive" hydrothermal circulation as it continues to evolve for many millions of years.

[57] Comparison between the computed layer 2B velocities and the hydrothermal circulation patterns inferred from heat flow, direct fluid flow and pore fluid geochemistry data reveals correlation of both up-flow or discharge zones with $2 \mathrm{~B}$ velocity lows and down-flow or recharge zones with $2 \mathrm{~B}$ velocity highs. This suggests that the pore clogging within upper layer $2 \mathrm{~B}$ takes place within the down-flow zones. In the vicinity of the ridge axis, where there is no or little sedimentary cover, up-flow zones are collocated with basement highs and down-flow zones with basement lows. Further away from the ridge axis, in areas where sediments fill basement lows to form minibasins, some of the basement highs appear to have been converted to down-flow zones indicating that both basement relief and sedimentary cover impact hydrothermal flow.

[58] The location of propagator wakes generally coincides with local minima in average upper $2 \mathrm{~B}$ velocity $(5.0 \pm 0.2 \mathrm{~km} / \mathrm{s})$, opposite of what appears to occur in layer $2 \mathrm{~A}$. The most likely explanation is that the denser network of fractures and cracks inherited from ridge propagation reduces velocities through the entire upper crust. However, layer 2A velocities are eventually augmented by mineral precipitation that, in crust older than $\sim 0.5 \mathrm{Ma}$, either does not extend into layer 2B or has little effect on it. The contribution of the hydrothermally driven downward propagating cracking front to off-axis layer $2 \mathrm{~A}$ thickening has not been imaged. If this process is active on the Juan de Fuca Ridge flanks, its contribution to the overall increase in layer $2 \mathrm{~A}$ thickness is much less than that of the off-axis emplacement of extrusive materials and is likely overprinted by the effects of other crustal evolutionary processes. The upper $2 \mathrm{~B}$ velocities along all three eastern ridge flanks within the area where normal faulting is observed appear to decrease as the crust ages and becomes more faulted. This suggests that the identified faulting potentially plays a role in layer $2 \mathrm{~B}$ evolution via increased porosity and rock alteration. Despite the overprinting of the structure inherited from crustal accretion by various geologic processes that, as the crust ages, often operate asymmetrically across the flanks, cospectra analysis indicates that at time scales $\geq 0.5 \mathrm{Ma}$ upper layer 2B velocities as a function of crustal age show similarities along the corresponding flanks.

\section{Acknowledgments}

[59] This research was supported by National Science Foundation grants OCE0002488 and OCE0648303 to S.M.C. and M.R.N., NSERC Discovery grant to M.R.N., and a Bruce C. Heezen Graduate Research Fellowship (Office of Naval Research grant N00014-02-1-0691) to K.R.N. We thank Bill Menke for fruitful discussions and reviewers Rick Carlson and Alistair Harding for their helpful input. We are grateful to Captain Mark Landow, Science Officer Joe Stennet, the crew, and the scientific and technical party of the R/V Maurice Ewing Cruise 02-07 for their support and help during the data acquisition.

\section{References}

Baran, J. M., S. M. Carbotte, J. R. Cochran, and M. R. Nedimović (2010), Upper crustal seismic structure along the Southeast Indian Ridge: Evolution from 0 to $550 \mathrm{ka}$ and variation with axial morphology, Geochem. Geophys. Geosyst., 11, Q02001, doi:10.1029/2009GC002629.

Becker, K., et al. (1989), Drilling deep into young oceanic crust, Hole 504B, Costa Rica Rift, Rev. Geophys., 27, 79-102, doi:10.1029/RG027i001p00079.

Berge, P. A., G. J. Fryer, and R. H. Wilkens (1992), Velocityporosity relationships in the upper oceanic crust: Theoretical considerations, J. Geophys. Res., 97, 15,239-15,254, doi:10.1029/92JB01464.

Bischoff, J. L., and W. E. Seyfried (1978), Hydrothermal chemistry of seawater from 25 degrees to 350 degrees C, Am. J. Sci., 278, 838-860, doi:10.2475/ajs.278.6.838.

Blackman, R. B., and J. W. Tukey (1958), The Measurement of Power Spectra, 190 pp., Dover, New York.

Bohnenstiehl, D. R., R. P. Dziak, M. Tolstoy, C. G. Fox, and M. Fowler (2004), Temporal and spatial history of the 1999 2000 Endeavour Segment seismic series, Juan de Fuca Ridge, Geochem. Geophys. Geosyst., 5, Q09003, doi:10.1029/ 2004GC000735.

Canales, J. P., R. S. Detrick, S. M. Carbotte, G. M. Kent, J. B. Diebold, A. Harding, J. Babcock, M. R. Nedimović, and E. van Ark (2005), Upper crustal structure and axial topography at intermediate spreading ridges: Seismic constraints from the southern Juan de Fuca Ridge, J. Geophys. Res., 110, B12104, doi:10.1029/2005JB003630.

Canales, J. P., B. E. Tucholke, M. Xu, J. A. Collins, and D. L. DuBois (2008), Seismic evidence for large-scale compositional heterogeneity of ocean core complexes, Geochem. Geophys. Geosyst., 9, Q08002, doi:10.1029/2008GC002009.

Carbotte, S. M., and D. S. Scheirer (2004), Variability of ocean crustal structure created along the global mid-ocean ridge, in Hydrogeology of the Oceanic Lithosphere, edited by E. E. Davis and H. Elderfield, pp. 59-107, Cambridge Univ. Press, New York.

Carbotte, S. M., J. C. Mutter, and L. Xu (1997), Contribution of volcanism and tectonism to axial and flank morphology of the southern East Pacific Rise, $17^{\circ} 10^{\prime}-17^{\circ} 14^{\prime}$ S, from a study 
of layer 2A geometry, J. Geophys. Res., 102, 10,165-10,184, doi:10.1029/96JB03910.

Carbotte, S. M., R. S. Detrick, A. J. Harding, J. P. Canales, J. Babcock, G. M. Kent, E. M. Van Ark, M. R. Nedimović, and J. B. Diebold (2006), Rift topography linked to magmatism at the intermediate spreading Juan de Fuca Ridge, Geology, 34, 209-212, doi:10.1130/G21969.1.

Carbotte, S. M., M. R. Nedimović, J. P. Canales, G. M. Kent, A. J. Harding, and M. Marjanović (2008), Variable crustal structure along the Juan de Fuca Ridge: Influence of on-axis hot spots and absolute plate motions, Geochem. Geophys. Geosyst., 9, Q08001, doi:10.1029/2007GC001922.

Carlson, R. L. (1998), Seismic velocities in the uppermost oceanic crust: Age dependence and the fate of layer 2A, J. Geophys. Res., 103, 7069-7077, doi:10.1029/97JB03577.

Carlson, R. L. (2010), How crack porosity and shape control seismic velocities in the upper oceanic crust: Modeling downhole logs from Holes 504B and 1256D, Geochem. Geophys. Geosyst., 11, Q04007, doi:10.1029/2009GC002955.

Chadwick, W. W., R. W. Embley, and C. G. Fox (1991), Evidence for volcanic eruptions on the southern Juan de Fuca Ridge between 1981 and 1987, Nature, 350, 416-418, doi:10.1038/350416a0.

Christensen, N. I. (1979), Compressional wave velocities in rocks at high temperatures and pressures, critical thermal gradients, and crustal low-velocity zones, J. Geophys. Res., 84, 6849-6857, doi:10.1029/JB084iB12p06849.

Christensen, N. I., and M. H. Salisbury (1975), Structure and constitution of the lower oceanic crust, Rev. Geophys., 13, 57-86, doi:10.1029/RG013i001p00057.

Christensen, N. I., and J. D. Smewing (1981), Geology and seismic structure of the northern section of the Oman ophiolite, J. Geophys. Res., 86, 2545-2555.

Christeson, G. L., G. M. Purdy, and K. M. M. Rohr (1993), Structure of the Northern Symmetrical segment of the Juan de Fuca Ridge, Mar. Geophys. Res., 15, 219-240, doi:10.1007/BF01204234.

Christeson, G. L., G. M. Kent, G. M. Purdy, and R. S. Detrick (1996), Extrusive thickness variability at the East Pacific Rise, $9^{\circ}-10^{\circ} \mathrm{N}$ : Constraints from seismic techniques, $\mathrm{J}$. Geophys. Res., 101, 2859-2873, doi:10.1029/95JB03212.

Christeson, G. L., K. D. McIntosh, and J. A. Karson (2007), Inconsistent correlation of seismic layer 2a and lava layer thickness in oceanic crust, Nature, 445, 418-421, doi:10.1038/ nature 05517.

Crawford, W. C., S. C. Webb, and J. A. Hildebrand (1999), Constraints on melt in the lower crust and Moho at the East Pacific Rise, $9^{\circ} 48^{\prime} \mathrm{N}$, using seafloor compliance measurements, J. Geophys. Res., 104, 2923-2939, doi:10.1029/ 1998JB900087.

Cudrak, C. F., and R. M. Clowes (1993), Crustal Structure of Endeavour Ridge segment, Juan de Fuca Ridge, from a detailed seismic refraction survey, J. Geophys. Res., 98, 6329-6349, doi:10.1029/92JB02860.

Davis, E. E., and J. L. Karsten (1986), On the cause of the asymmetric distribution of seamounts about the Juan de Fuca Ridge: Ridge-crest migration over a heterogeneous asthenosphere, Earth Planet. Sci. Lett., 79, 385-396, doi:10.1016/ 0012-821X(86)90194-9.

Davis, E. E., et al. (1992), FlankFlux: And experiment to study the nature of hydrothermal circulation in young oceanic crust, Can. J. Earth Sci., 29, 925-952.

Detrick, R. S., J. Collins, R. Stephen, and S. Swift (1994), In situ evidence for the nature of the seismic layer $2 / 3$ boundary in oceanic crust, Nature, 370, 288-290, doi:10.1038/ 370288a0.

Embley, R. W., J. Chadwick, W. William, M. R. Perfit, and E. T. Baker (1991), Geology of the northern Cleft segments, Juan de Fuca Ridge: Recent lava flows, sea-floor spreading, and the formation of megaplumes, Geology, 19, 771-775, doi:10.1130/0091-7613(1991)019<0771:GOTNCS $>2.3$. $\mathrm{CO} ; 2$.

Fisher, A. T., et al. (2003), Hydrothermal recharge and discharge across $50 \mathrm{~km}$ guided by seamounts on a young ridge flank, Nature, 421, 618-621, doi:10.1038/nature01352.

Goldstein, S. J., M. R. Perfit, R. Batiza, D. J. Fornari, and M. T. Murrell (1994), Off-axis volcanism at the East Pacific Rise detected by uranium-series dating of basalts, Nature, 367, 157-159, doi:10.1038/367157a0.

Grevemeyer, I., and W. Weigel (1996), Seismic velocities of the uppermost igneous crust versus age, Geophys. J. Int., 124, 631-635, doi:10.1111/j.1365-246X.1996.tb07041.x.

Grevemeyer, I., W. Weigel, and C. Jennrich (1998), Structure and ageing of oceanic crust at $14^{\circ} \mathrm{S}$ on the East Pacific Rise, Geophys. J. Int., 135, 573-584, doi:10.1046/j.1365246X.1998.00673.x.

Harding, A. J., G. M. Kent, and J. A. Orcutt (1993), A multichannel seismic investigation of upper crustal structure at $9^{\circ} \mathrm{N}$ on the East Pacific Rise: Implications for crustal accretion, J. Geophys. Res., 98, 13,925-13,944, doi:10.1029/93JB00886.

Haymon, R. M., et al. (1993), Volcanic eruption of the midocean ridge along the East Pacific Rise crest at $9^{\circ} 45-52^{\prime} \mathrm{N}$ : Direct submersible observations of seafloor phenomena associated with an eruption event in April, 1991, Earth Planet. Sci. Lett., 119, 85-101, doi:10.1016/0012-821X(93) 90008-W.

Hooft, E. E. E., and R. S. Detrick (1995), Relationship between axial morphology, crustal thickness, and mantle temperature along the Juan de Fuca and Gorda Ridge, J. Geophys. Res., 100, 22,499-22,508, doi:10.1029/95JB02502.

Hooft, E. E. E., H. Schouten, and R. S. Detrick (1996), Constraining crustal emplacement processes from the variation of seismic layer 2A thickness at the East Pacific Rise, Earth Planet. Sci. Lett., 142, 289-309, doi:10.1016/0012-821X(96) 00101-X.

Houtz, R., and J. Ewing (1976), Upper crustal structure as a function of plate age, J. Geophys. Res., 81, 2490-2498, doi:10.1029/JB081i014p02490.

Hunter, A. G., P. D. Kempton, and P. Greenwood (1999), Low-temperature fluid-rock interaction-An isotopic and mineralogical perspective of upper crustal evolution, eastern flank of the Juan de Fuca Ridge (JdFR), ODP Leg 168 , Chem. Geol., 155, 3-28, doi:10.1016/S0009-2541(98) 00138-7.

Hussenoeder, S. A., R. S. Detrick, G. M. Kent, H. Schouten, and A. J. Harding (2002a), Fine-scale seismic structure of young upper crust at $17^{\circ} 20^{\prime} \mathrm{S}$ on the fast spreading East Pacific Rise, J. Geophys. Res., 107(B8), 2158, doi:10.1029/ 2001JB001688.

Hussenoeder, S. A., G. M. Kent, and R. S. Detrick (2002b), Upper crustal seismic structure of the slow spreading MidAtlantic Ridge, $35^{\circ} \mathrm{N}$ : Constraints on volcanic emplacement processes, J. Geophys. Res., 107(B8), 2156, doi:10.1029/ 2001JB001691.

Jacobson, R. S. (1992), Impact of crustal evolution on changes of the seismic properties of the uppermost ocean crust, Rev. Geophys., 30, 23-42, doi:10.1029/91RG02811.

Jenkins, G. M., and D. G. Watts (1968), Spectral Analysis and Its Applications, 525 pp., Holden Day, San Francisco, Calif. 
Johnson, H. P., B. Keir, and R. Von Herzen (1993), Near-axis heat flow measurements on the northern Juan de Fuca ridge: Implications for fluid circulation in oceanic crust, Geophys. Res. Lett., 20, 1875-1878.

Johnston, J. E., and N. I. Christensen (1997), Seismic properties of layer 2 basalts, Geophys. J. Int., 128, 285-300, doi:10.1111/j.1365-246X.1997.tb01555.x.

Kappel, E. S., and W. B. F. Ryan (1986), Volcanic episodicity and a non-steady state rift valley along northeast Pacific spreading centers: Evidence from Sea MARC I, J. Geophys. Res., 91, 13,925-13,940, doi:10.1029/JB091iB14p13925.

Kappus, M. E., A. J. Harding, and J. A. Orcutt (1995), A baseline for upper crustal velocity variations along the East Pacific Rise at $13^{\circ} \mathrm{N}, J$. Geophys. Res., 100, 6143-6161, doi:10.1029/94JB02474.

Karson, J. A. (1998), Internal structure of oceanic lithosphere: A perspective from tectonic windows, in Faulting and Magmatism at Mid-ocean Ridges, Geophys. Monogr. Ser., vol. 106, edited by W. R. Buck et al., pp. 177-218, AGU, Washington, D. C.

Karson, J. A., and G. L. Christeson (2003), Comparison of geologic and seismic structure of uppermost fast-spread oceanic crust: Insights from a crustal cross section at the Hess Deep Rift, in Heterogeneity in the Crust and Upper Mantle: Nature, Scaling and Seismic Properties, edited by J. Goff and K. Holliger, pp. 99-129, Kluwer Acad., New York.

Karsten, J. L., and J. R. Delaney (1989), Hot spot-ridge crest convergence in the northeast Pacific, J. Geophys. Res., 94, 700-712, doi:10.1029/JB094iB01p00700.

Karsten, J. L., S. R. Hammond, E. E. Davis, and R. G. Currie (1986), Detailed geomorphology and neotectonics of the Endeavour Segment, Juan de Fuca Ridge: New results from Seabeam swath mapping, Geol. Soc. Am. Bull., 97, 213-221, doi:10.1130/0016-7606(1986)97<213:DGANOT>2.0.CO;2.

Kelley, D. S., J. R. Delaney, and D. R. Yoerger (2001), Geology and venting characteristics of the Mothra hydrothermal field, Endeavour Segment, Juan de Fuca Ridge, Geology, 29, 959-962, doi:10.1130/0091-7613(2001)029<0959: GAVCOT $>2.0 . \mathrm{CO} ; 2$.

Kelley, D. S., J. A. Baross, and J. R. Delaney (2002), Volcanoes, fluids and life at mid-ocean ridge spreading centers, Annu. Rev. Earth Planet. Sci., 30, 385-491, doi:10.1146/annurev. earth.30.091201.141331.

Kelley, D. S., J. R. Delaney, M. D. Lilley, D. A. Butterfield, and J. D. Baross (2003), Geological, biological, and chemical linkages within the Endeavour hydrothermal system, in Geoscience Horizons: Seattle 2003: Abstracts with Programs, vol. 3, p. 220, Geol. Soc. of Am., Boulder, Colo.

Kent, G. M., A. J. Harding, J. A. Orcutt, R. S. Detrick, J. C. Mutter, and P. Buhl (1994), Uniform accretion of oceanic crust south of the Garrett transform at $14^{\circ} 15^{\prime} \mathrm{S}$ on the East Pacific Rise, J. Geophys. Res., 99, 9097-9116, doi:10.1029/ 93JB02872.

Kleinrock, M. C., and R. N. Hey (1989), Detailed tectonics near the tip of the Galapagos $95.5^{\circ} \mathrm{W}$ propagator: How the lithosphere tears and a spreading axis develops, J. Geophys. Res., 94, 13,801-13,838, doi:10.1029/JB094iB10p13801.

Langseth, M. G., M. J. Mottl, M. A. Hobart, and A. Fisher (1988), The distribution of geothermal and geochemical gradients near Site 501/1504: Implications for hydrothermal circulation in the oceanic crust, Proc. Ocean Drill. Program Initial Rep., 111, 23-32.

Lilley, M. D., M. C. Landsteiner, E. A. McLaughlin, C. B. Parker, A. S. M. Cherkaoui, G. Lebon, S. R. Viers, and J. R. Delaney (1995), Real-time mapping of hydrothermal plumes on the Endeavour Segment of the Juan de Fuca, Eos Trans. $A G U, 76$, Fall Meet. Suppl., F420.

Lister, C. R. B. (1974), On the penetration of water into hot rock, Geophys. J. R. Astron. Soc., 39, 465-509.

Macdonald, K. C., R. Haymon, and A. Shor (1989), A $220 \mathrm{~km}^{2}$ recently erupted lava field on the East Pacific Rise near lat $8^{\circ} \mathrm{S}$, Geology, 17, 212-216, doi:10.1130/0091-7613(1989) $017<0212$ :AKRELF $>2.3$. CO;2.

McClain, J. S., J. A. Orcutt, and M. Burnett (1985), The East Pacific Rise in cross section: A seismic model, J. Geophys. Res., 90, 8627-8693, doi:10.1029/JB090iB10p08627.

Miller, J. M., G. J. Iturrino, and N. I. Christensen (1996), Geochemical and petrological constraints on velocity behavior of lower crustal and upper mantle rocks from the fast-spreading ridge at Hess Deep, Proc. Ocean Drill. Program Sci. Results, 147, 477-490.

Mooney, W. D., and A. Ginzburg (1986), Seismic measurements of the internal properties of fault zones, Pure Appl. Geophys., 124, 141-157, doi:10.1007/BF00875723.

Mutter, C. Z., and J. C. Mutter (1993), Variations in thickness of layer 3 dominate oceanic crustal structure, Earth Planet. Sci. Lett., 117, 295-317, doi:10.1016/0012-821X(93) 90134-U.

Nedimović, M. R., S. M. Carbotte, A. J. Harding, R. S. Detrick, J. P. Canales, G. M. Kent, M. Tischer, J. B. Diebold, and J. M. Babcock (2005), Frozen subcrustal magma lenses, Nature, 436, 1149-1152, doi:10.1038/nature03944

Nedimović, M. R., S. M. Carbotte, J. B. Diebold, A. J. Harding, J. P. Canales, and G. M. Kent (2008), Upper crustal evolution along the Juan de Fuca ridge flanks, Geochem. Geophys. Geosyst., 9, Q09006, doi:10.1029/2008GC002085.

Nedimović, M. R., D. R. Bohnenstiehl, S. M. Carbotte, J. P. Canales, and R. P. Dziak (2009), Faulting and hydration of the Juan de Fuca plate system, Earth Planet. Sci. Lett., 284, 94-102, doi:10.1016/j.epsl.2009.04.013.

Pelayo, A. M., S. Stein, and C. A. Stein (1994), Estimation of oceanic heat flux from heat flow and depths of midocean ridge seismicity and magma chambers, Geophys. Res. Lett., 21, 713-716, doi:10.1029/94GL00395.

Percival, D. B., and A. T. Walden (1993), Spectral Analysis for Physical Applications, 583 pp., doi:10.1017/ CBO9780511622762, Cambridge Univ. Press, Cambridge, U. K.

Perfit, M. R., D. J. Fornari, M. C. Smith, J. F. Bender, C. H. Langmuir, and R. M. Haymon (1994), Small-scale spatial and temporal variations in mid-ocean ridge crest magmatic processes, Geology, 22, 375-379.

Priestley, M. B. (1981), Spectral Analysis and Time Series, 890 pp., Academic, London.

Purdy, G. M., and J. Ewing (1986), Seismic structure of the ocean crust, in The Geology of North America, vol. M, The Western North Atlantic Region, edited by P. R. Vogt and B. E. Tucholke, pp. 313-330, Geol. Soc. of Am., Boulder, Colo.

Raitt, R. W. (1963), The crustal rocks, in The Sea, vol. 3, The Earth Beneath the Sea History, edited by M. N. Hill, pp. 85-102, Wiley-Interscience, New York.

Robigou, V., J. R. Delaney, and D. S. Stakes (1993), Large massive sulfide deposits in a newly discovered active hydrothermal system, the High-Rise field, Endeavour segment, Juan de Fuca Ridge, Geophys. Res. Lett., 20, 1887-1890, doi:10.1029/93GL01399.

Rohr, K. M. M. (1994), Increase of seismic velocities in upper oceanic crust and hydrothermal circulation in the Juan de 
Fuca plate, Geophys. Res. Lett., 21(19), 2163-2166, doi:10.1029/94GL01913.

Shoberg, T., S. Stein, and J. Karsten (1991), Constraints on rift propagation history at the Cobb Offset, Juan de Fuca Ridge, from numerical modeling of tectonic fabric, Tectonophysics, 197, 295-308, doi:10.1016/0040-1951(91)90047-V.

Sleep, N. H. (1991), Hydrothermal circulation, anhydrite precipitation, and thermal structure at ridge axes, J. Geophys. Res., 96, 2375-2387, doi:10.1029/90JB02335.

Smith, M. C., M. R. Perfit, and I. R. Jonasson (1994), Petrology and geochemistry of basalts from the southern Juan de Fuca Ridge: Controls on the spatial and temporal evolution of mid-ocean ridge basalt, J. Geophys. Res., 99, 4787-4812, doi:10.1029/93JB02158.

Soule, S. A., D. J. Fornari, M. R. Perfit, and K. H. Rubin (2007), New insights into mid-ocean ridge volcanic processes from the 2005-2006 eruption of the East Pacific Rise, $9^{\circ} 46^{\prime} \mathrm{N}-9^{\circ} 56^{\prime} \mathrm{N}$, Geology, 35, 1079-1082, doi:10.1130/ G23924A.1.

Stein, C. A., and S. Stein (1994), Constraints on hydrothermal heat flux though oceanic lithosphere from global heat flow, J. Geophys. Res., 99, 3081-3095, doi:10.1029/93JB02222.

Swift, S., M. Reichow, A. Tikku, M. Tominaga, and L. Gilbert (2008), Velocity structure of upper ocean crust at Ocean Drilling Program Site 1256, Geochem. Geophys. Geosyst., 9, Q10O13, doi:10.1029/2008GC002188.

Talwani, M., C. C. Windisch, and M. G. Langseth (1971), Reykjanes ridge crest: A detailed geophysical study, J. Geophys. Res., 76, 473-517, doi:10.1029/JB076i002p00473.

Teagle, D. A. H., J. C. Alt, and A. N. Halliday (1998), Tracing the chemical evolution of fluids during hydrothermal recharge: Constraints from anhydrite recovered in ODP Hole 504B, Earth Planet. Sci. Lett., 155, 167-182, doi:10.1016/ S0012-821X(97)00209-4.

Tivey, M. K., and J. R. Delaney (1986), Growth of large sulfide structures on the Endeavour segment of the Juan de Fuca Ridge, Earth Planet. Sci. Lett., 77, 303-317, doi:10.1016/0012-821X(86)90142-1.

Toomey, D. R., G. M. Purdy, S. C. Solomon, and W. Wilcox (1990), The three dimensional seismic velocity structure of the East Pacific Rise near latitude $9^{\circ} 30^{\prime} \mathrm{N}$, Nature, 347, 639-645, doi:10.1038/347639a0.

Van Ark, E. M., R. S. Detrick, J. P. Canales, S. M. Carbotte, A. J. Harding, G. M. Kent, M. R. Nedimović, W. S. D.
Wilcock, J. B. Diebold, and J. M. Babcock (2007), Seismic structure of the Endeavour Segment, Juan de Fuca Ridge: Correlation with seismicity and hydrothermal activity, J. Geophys. Res., 112, B02401, doi:10.1029/2005JB004210.

Vera, E. E., and J. B. Diebold (1994), Seismic imaging of layer $2 \mathrm{~A}$ between $9^{\circ} 30^{\prime} \mathrm{N}$ and $10^{\circ} \mathrm{N}$ on the East Pacific Rise from two-ship wide-aperture profiles, J. Geophys. Res., 99, 3031-3041, doi:10.1029/93JB02107.

Vera, E. E., J. C. Mutter, P. Buhl, J. A. Orcutt, A. J. Harding, M. E. Kappus, R. S. Detrick, and T. M. Brocher (1990), The structure of 0 - to $0.02-\mathrm{m} . \mathrm{y}$.-old oceanic crust at $9^{\circ} \mathrm{N}$ on the East Pacific Rise from expanded spread profiles, J. Geophys. Res., 95, 15,529-15,556, doi:10.1029/JB095iB10p15529.

Wang, K., J. He, and E. E. Davis (1997), Influence of basement topography on hydrothermal circulation in sedimentburied igneous oceanic crust, Earth Planet. Sci. Lett., 146, 151-164, doi:10.1016/S0012-821X(96)00213-0.

Wilcock, W. S. D., S. C. Solomon, G. M. Purdy, and D. R. Toomey (1992), The seismic attenuation structure of a fast-spreading mid-ocean ridge, Science, 258, 1470-1474, doi:10.1126/science.258.5087.1470.

Wilkens, R. H., F. J. Fryer, and J. Karsten (1991), Evolution of porosity and seismic structure of upper oceanic crust: Importance of aspect ratios, J. Geophys. Res., 96, 17,981-17,995, doi:10.1029/91JB01454.

Williams, D. L., R. P. Von Herzen, J. G. Sclater, and R. N. Anderson (1974), The Galapagos spreading centre: Lithospheric cooling and hydrothermal circulation, Geophys. J. R. Astron. Soc., 38, 587-608.

Wilson, D. S. (1993), Confidence intervals for motion and deformation of the Juan de Fuca plate, J. Geophys. Res., 98, 16,053-16,071, doi:10.1029/93JB01227.

Wilson, D. G., et al. (2006), Drilling to gabbro in intact oceanic crust, Science, 312, 1016-1020, doi:10.1126/science.1126090.

Zelt, C. A., and P. J. Barton (1998), Three-dimensional seismic refraction tomography: A comparison of two methods applied to data from the Faeroe Basin, J. Geophys. Res., 103, 7187-7210, doi:10.1029/97JB03536.

Zelt, B. C., B. Taylor, J. R. Weiss, A. M. Goodliffe, M. Sachpazi, and A. Hirn (2004), Streamer tomography velocity models for the Gulf of Corinth and Gulf of Itea, Greece, Geophys. $J$. Int., 159, 333-346, doi:10.1111/j.1365-246X.2004.02388.x. 